NBER WORKING PAPER SERIES

\title{
NEGATIVE BUBBLES: WHAT HAPPENS AFTER A CRASH
}

\author{
William N. Goetzmann \\ Dasol Kim
}

Working Paper 23830

http://www.nber.org/papers/w23830

\author{
NATIONAL BUREAU OF ECONOMIC RESEARCH \\ 1050 Massachusetts Avenue \\ Cambridge, MA 02138 \\ September 2017, January 2018
}

The authors thank John Doukas (the Editor), Antti Ilmanen, Tyler Muir, Justin Murfin, Robert Shiller and the conference seminar participants at the Bank of England and participants in the European Financial Management Association Meeting in Athens, 2017. We thank Elroy Dimson, Paul Marsh and Mike Staunton for the use of their annual DMS data and acknowledge Global Financial Data \& the International Center for Finance at the Yale School of Management as the source of monthly global market data. The opinions expressed are those of the authors and do not necessarily reflect those of the Office of Financial Research, the U.S. Department of the Treasury, or the National Bureau of Economic Research.

NBER working papers are circulated for discussion and comment purposes. They have not been peer-reviewed or been subject to the review by the NBER Board of Directors that accompanies official NBER publications.

(C) 2017 by William N. Goetzmann and Dasol Kim. All rights reserved. Short sections of text, not to exceed two paragraphs, may be quoted without explicit permission provided that full credit, including $\odot$ notice, is given to the source. 
Negative Bubbles: What Happens After a Crash

William N. Goetzmann and Dasol Kim

NBER Working Paper No. 23830

September 2017, January 2018

JEL No. G02,G11,G15,G17

\title{
ABSTRACT
}

We study crashes using data from 101 global stock markets from 1692 to 2015 . Extremely large, annual stock market declines are typically followed by positive returns. This is not true for smaller declines. This pattern does not appear to be driven by institutional frictions, financial crises, macroeconomic shocks, political conflicts, or survivorship issues.

\author{
William N. Goetzmann \\ School of Management \\ Yale University \\ Box 208200 \\ New Haven, CT 06520-8200 \\ and NBER \\ william.goetzmann@yale.edu \\ Dasol Kim \\ Office of Financial Research \\ U.S. Department of Treasury \\ 717 14th St NW \\ Washington, DC 20005 \\ dasolkim@gmail.com
}




\section{Introduction}

Although stock market crashes are few and far between, they seem to constantly concern investors. Analyzing investor surveys over the period 1989 to 2016, Goetzmann, Kim and Shiller (2017) find that the average individual investor, responding to a survey, estimated that a catastrophic stock market crash had a $20 \%$ chance of happening within the next six months. Their findings suggest a high level of fear about the consequences of a market crash. In this paper, we explore whether such fears are justified.

We use data from more than 100 global stock markets over three centuries to examine market dynamics after major crashes. The large collection of markets and broad sweep of time afforded by the data allow us to identify a larger number of related events than possible when focusing on a specific market or more limited time period. We define a crash in various ways as a rapid and unusually large decline in a national stock market index. We identify 1,032 events for which a market declined by more than $50 \%$ over a 12 -month period. Conditioning on these events, and controlling for a range of other factors, we find that markets tend to rebound in the year following the crash. We refer to this pattern of crash-and-rebound as a "negative bubble." Interestingly, the pattern only holds for large crashes - declines of lesser magnitude exhibit persistence, not reversal. This non-linearity presents a challenge to standard econometric forecasting techniques and suggests that something more complex than mean-reversion is at work.

We consider some proposed macroeconomic, institutional, and sample selection explanations for this pattern. Macroeconomic explanations include changing volatility, inflation risk and disaster risk as potential drivers of temporary asset price declines. Institutional explanations include financial sector fragility and constraints on arbitrage. Selection bias theories posit that ex-post data collection omits markets that failed to rebound. We find negative bubbles 
are not well explained by macroeconomic or institutional factors. Selection bias also does not seem to drive the results. Alternatively, there are behavioral theories that are consistent with the findings. They include panics or other temporary shocks to sentiment, and bubbles - temporary, irrational over-pricing leading to a crash. While promising, they are difficult to test.

\section{Background}

There is a long literature of forecasting long-horizon stock market returns, much of it modeling a linear relationship between a set of macroeconomic state variables and future returns. Although the limitations of this approach have been studied and discussed, the consensus is that some combination of past returns, financial ratios and discount rate proxies have predictive power. This large body of work seeks to identify some model or consistent rules that govern market behavior under a complete range of conditions. Our approach in this paper is different in that we focus narrowly on extreme events in order to document a comprehensive set of outcomes. We then explore varying conditions that may have affected outcomes, and compare these to proposed theories. Documenting historical outcomes may not provide a complete guide to predicting future consequences of a stock market crash, but it is better than relying on personal experience, or selective anecdotes about prior crashes. Thus, our modest goal is to report the frequency of market crashes and the distribution of subsequent returns.

Our second goal is to evaluate some of the theories proposed to explain the dynamics of markets following crashes. Muir (2017) documents a V-shape in asset prices specifically associated with financial crises over 140 years of history and 14 markets. Notably this pattern is not associated with more fundamental factors such as consumption shocks or other major macroeconomic events. Rather, asset price dips may reflect distress caused by over-leveraged 
financial institutions (cf. Brunnermeier \& Sannikov, 2014). Financial constraints have been shown to cause fire sales in asset prices, which are then followed by a rebound (cf. Brunnermeier \& Pederson, 2008; Geanakoplos, 2010; Gromb \& Vayanos, 2009; and Richardson, Saffi and Sigurdsson, 2017). Coval and Stafford (2007) document this pattern for stocks held by mutual funds experiencing large outflows. In short, both asset supply and demand are affected by institutional distress. On the supply side, banks and arbitrageurs may be forced to de-risk by selling assets. On the demand side, distressed banks may restrict credit to arbitrageurs in periods when assets are priced cheap.

We test these hypotheses in two ways. First, we test whether crashes coincident with financial crises are more or less likely to rebound. ${ }^{1}$ We find little evidence that financial crises matter when we condition upon a major crash of a 50 percent decline or more. Second, we compare market returns following globally uncorrelated crashes. Assuming that crashes that occur globally are more likely to be associated with constraints on arbitrage, the financial constraint hypothesis predicts rebounds are less likely following uncorrelated crashes - i.e. when the average return across markets in that year is above the sample median. We find evidence for negative bubbles even during these periods.

Broadly speaking, macroeconomic explanations attribute asset price dynamics to changes in expected returns and discount rates driven by fundamental variables. Proposed explanatory variables are legion but commonly include valuation ratios, discount rate proxies, measures of economic activity and realized or anticipated rare disasters. Berkman, Jacobsen and Lee (2011) find a V-shaped pattern in stock returns around political conflicts: a decline in returns during a crisis and an increase in returns after its resolution. Bialkowski and Ronn (2016) emphasize the

\footnotetext{
${ }^{1}$ We rely on the assumption that we have a comprehensive set of financial crises for the countries we study.
} 
existential threat that these crises represented to investors, which might explain the severity of a crash's price decline relative to the ex-post level. Barro and Ursúa (2017) show that stock market crashes, defined by peak to trough magnitude are associated with depressions.

Our dataset lacks financial ratio information to assess changing expected returns for a large part of the sample, but we use other variables in our analysis that have been shown to potentially determine return expectations and discount rates. These include past market returns, volatility, and fixed effects based upon time and country. For a subset of the sample where more information is available, we also control for depression periods, changes in GDP, inflation shocks, financial crises, aggregate debt, and dividend yields. While some of these are significant market predictors, we find little evidence that they explain the pattern of negative bubbles.

To test whether our results are due to backfill or survival bias, we use a sample of markets not subject to these biases. Jorion and Goetzmann (1999) collect a sample of 39 markets using a "follow-forward" methodology using market indexes maintained in real time by the League of Nations, the United Nations and the IFC. This sample includes many markets that traded in the early $20^{\text {th }}$ century and subsequently disappeared until the post-Soviet era. This sample is augmented to include pre-revolutionary Russia and China and extended forward without additions to create a sample that is unlikely to have survival bias and minimal backfill bias. These data give substantially the same results. Even taking into account markets that crashed and failed, the negative bubble pattern is significant.

Finally, one behavioral explanation for the rebound pattern is that the crash was due to temporary, severe negative sentiment about the stock market. Shiller (2000) notes that feedback theories may apply to price declines in addition to runups - he refers to the former as a "negative bubble." Initial price declines may discourage some investors from investing, causing further 
declines. Temporary bouts of pessimism or exuberance could generally manifest as mean reversion, but in the extreme might appear as a positive or negative market bubble. Following the crash of 1987, Seyhun (1990) documents significantly larger buying activities by corporate insiders than in years prior to the crash, and shows that stocks that were extensively purchased by insiders were associated with higher returns in the following year. The results are consistent with investor overreaction during the crash. Moskowitz, Ooi and Pedersen (2012) document positive price predictability for a large number of asset classes based upon past year excess returns. The effects are persistent for up to one-year, and reverse over longer horizons. Their findings are consistent with initial under-reaction and delayed overreaction which in turn are predicted by theories of sentiment. Evidence in Goetzmann, Kim and Shiller (2017) suggests that market participants are consistently pessimistic vis-à-vis prospects for a major market crash. Crash fears implied by equity risk premium models and implied by option prices likewise suggest a consistent pessimism about an extreme event.

Our results have implications for investment policy. Investors chase market performance. A crash in asset prices may stimulate disinvestment from equity markets. Ang, Goyal and Ilmanen (2014) document pro-cyclical equity allocation by U.S. pension funds; Jones (2016) extends this analysis to other institutional investor classes. Both find that the 2008 crash and the bursting of the Dot-com bubble resulted in reduced equity allocation. Crashes may influence both expectations and attitudes about future market returns. Goetzmann, Kim and Shiller (2017) find that an increase in investor crash probabilities is associated with decreases in fund flows to equity mutual funds. Consequently, it is valuable to demonstrate what history has to tell us about the actual trajectory of markets following a crash. 


\section{Data}

Our data come from three sources. For much of our analysis we use monthly capital appreciation real returns for 101 of the world's stock markets from Global Financial Data [GFD] from 1692 to $2015 .^{2}$ Dividend yield data is also available, but only for a limited number of markets. GFD has collected price information from a wide variety of sources documented on their website. The UK series extends back the farthest; the earliest crash in the data is the 12-month period following the bursting of the South Sea Bubble. Figure 1 shows the growth in the number of markets through time. ${ }^{3}$ There were two growth spurts in the number of markets in the sample: from 1900 to 1934 the number grew from 6 to 32, which was a high-water mark until 1949. Steady growth followed by the most recent period of market growth was in the period 1988 to 2003 when the count went from 54 to 94.

Figure 1 also suggest that survivorship bias might not be a great concern. There are intervals over which the number of markets declined due to market closures or interruptions in data reporting. Years in which the aggregate number dropped by more than one market include 1914, 1931, 1939 and 1945. These years are associated with severe geopolitical events. As an additional check on the results, we construct annual real returns based on a set of stock markets over the period 1919-1996 collected by Jorion and Goetzmann (1999) [JG], which by construction is largely survival-bias-free. The benefit of using monthly data is that it provides a much richer sample of crashes. For example, the crash of 1987 was the most extreme crash in US market history, but the year 1987 was not itself unusual. However, the analysis of data derived from a different source is a useful cross-check, and analysis at the annual horizon allows us to dispense with corrections for overlapping observations.

\footnotetext{
${ }^{2}$ Described in Taylor (2005), the data was obtained from https://WwW.globalfinancialdata.com/.

${ }^{3}$ The database corresponds well with the markets documented in Goetzmann, Li and Rouwenhorst (2005).
} 
Annual macroeconomic data and information about financial crises for a subsample of the markets in the GFD sample from 1870 to 2008 is obtained from a number of different sources. Depression dates are obtained from Barro and Ursúa (2017). Real GDP data is obtained from Barro and Ursúa (2008). ${ }^{4}$ Data on inflation, credit, and financial crisis dates are obtained from Jordà, Schularick and Taylor (2017). ${ }^{5}$ Data on political conflicts are obtained from International Crisis Behavior Project (Version 11). ${ }^{6}$ Table 1 displays the descriptions and summary statistics of variables used in the analysis.

\section{Conditional Distributions: Methodology and Results}

In this section, we document the performance of country stock indexes following crashes. We categorize crashes from mild to extreme: from negative returns over a twelve-month period to a decline of -50 percent or more over a twelve-month period. We then measure market performance in the 12-month, 24-month and 36-month periods following crashes, classifying these according to whether returns were positive or negative and whether they are extreme. Classification in this way allows us to document whether mild or extreme crashes are followed by further declines or a rebound.

We begin with an analysis of overlapping annual returns constructed from monthly data. Table 2 shows the distinct pattern we document in this paper. Each row in the table classifies the twelve-month return following a crash in the prior twelve months, with row 1 displaying the summary statistics for the unconditional sample. The definition of a crash varies from a simple

4 The version of the data spanning from 1790 to 2009 can be downloaded at https://scholar. harvard.edu/barro/publications/barro-ursua-macroeconomicdata/.

$\overline{5}$ The data is available at http://www. macrohistory. net/data/.

${ }^{6}$ The data is available at https://sites.duke.edu/icbdata/. 
negative return (row 2), to a decline of $-50 \%$ or more (row 7). Counts of these events are given in the second column. There were 1,032 crashes of at least $-50 \%$ in the sample, and these represent 1.8 percent of the total observations. Consider first the columns for a positive vs. negative subsequent returns conditional on a crash. These are labeled $(0 \%,+\infty)$ and $[-100 \%, 0 \%)$. A year after a negative market move, returns were more often negative. However, as the severity of the prior year crash increases, the balance shifts dramatically. After a decline of $-50 \%$ or more, the probability of a positive year is approximately $60 \%$. Notice also that after large crashes, the distribution of returns spreads. This is likely due to the fact that more volatile markets are more likely to experience a large crash in the first place. However, the probability of an extreme positive event is higher compared to an extreme negative one. For example, the probability of a positive $25 \%$ return in the next year is approximately twice that of a negative $25 \%$ return. One limitation of the results in Table 2 is that they do not control for a range of factors potentially relevant to distribution of future returns.

To address the need for controls, we specify dummy variable regressions for which the dependent variable is an indicator for a given level of returns in the 12-month period following a crash, or between months $t+1$ to $t+12$, and the explanatory variables are indicators for varying degrees of severity of the crash between months $t-11$ to $t .^{7}$ We include return volatility over months $t-11$ to $t$, and change in return volatility between months $t-11$ to $t$ and $t-23$ to $t-12$. Also included are cumulative returns from months $t-11$ to $t$; cumulative returns from months $t-23$ to $t-12$; and cumulative returns from months $t-35$ to $t-24$. To account for time-invariant country factors and global macroeconomic events, country and date fixed effects are included where indicated, but not reported. Finally, given that the return variables are overlapping within the panel, we use Driscoll

\footnotetext{
${ }^{7}$ While it is common to specify this as a logistic regressions Hellevik (2009) demonstrates that, in practice the linear regression is robust and is preferred for questions of causal inference.
} 
and Kraay standard errors (cf. Driscoll \& Kraay, 1998), which accounts for potential serial correlation and cross-sectional dependency in the residuals, for the test statistics.

Specifically, we estimate the following econometric specification:

$$
I\left(r_{t+1, t+12} \in[J]\right)=\sum_{i} \alpha_{i} I\left(r_{t-11, t} \in\left[\tau_{i_{1}}, \tau_{i_{2}}\right)\right)+\sum_{j} \gamma_{j} z_{t, j}+F E+\varepsilon_{t}
$$

where the indicator variable $I\left(r_{t+1, t+12} \in[J]\right)$ is 1 when the return for the subsequent year is in bin J (i.e., $[-100 \%,-50 \%))$, and zero otherwise. Indicator variables $I\left(r_{t-11, t} \in\left[\tau_{i_{1}}, \tau_{i_{2}}\right)\right)$ are 1 when the prior return is lower than the threshold $\tau_{i_{2}}$ but at least $\tau_{i_{1}}$. The ranges we use for the indicator variables based upon the prior return are $[-100 \%,-50 \%),[-50 \%,-40 \%),[-40 \%,-30 \%),[-30 \%,-$ $20 \%),[-20 \%,-10 \%)$, and $[-10 \%, 0 \%) . z_{t, j}$ denote control variables and FE represent both country and date fixed effects. We report the main results with and without the control variables and fixed effects to assess sensitivity to the specifications, given that the full model includes both the country fixed effects and the lagged dependent variable.

Table 3 reports the results of estimating equation (1). Panel A reports the results with no control variables or fixed effects, while Panel B includes both. In Panel A, consistent with the results in Table 2, row 1 shows that a negative return (Model (4)) is positively associated with a prior negative 12-month return, and a positive return (Model (5)) is negatively associated with a prior year decline. Focusing on the last two rows of Panel A, however, note that there is a strong positive and significant association between crashes of large magnitude and subsequent returns of large magnitude. This is the V-shape, rebound or "negative bubble" pattern noted in Table 2.

In Panel B of Table 3, the addition of control variables and fixed effects appears to clarify some of the results in Panel A. The rebound pattern remains strongly significant (evident in the lower right corner of the panel). For smaller crashes, prior returns are negatively associated with subsequent large positive returns and positively associated with all categories of negative 
subsequent returns. For a major crash of at least $-50 \%$, the increased probability of a subsequent rebound of at least $+50 \%$ is $10.5 \%$ using the Panel B estimates $(17.8 \%$ using the Panel A estimates). While not reported, the fixed effects and control variables contribute significantly to the explanatory power of the regressions in Table 3. Importantly, they account for differences in market volatility, volatility shocks, mean reversion in long-horizon returns, global events and the country-specific characteristics, such as persistent political institutions and trade relationships. Qualitatively, the effects are not sensitive to the inclusion of the control variables and fixed effects. ${ }^{8}$

Panel B of Table 3 also shows that modest, prior year declines ( $0 \%$ to $-10 \%$ and $-10 \%$ to $20 \%$ ) are positively associated with large declines in the following year, and negatively associated with large subsequent gains. This is consistent with Barro and Ursúa (2017) who focus on market declines of $-25 \%$ from peak to trough which may extend over time horizons of multiple years market declines may indeed forecast adverse future economic conditions and severe future drops.

Table 4 reports the results of five model specifications with long-horizon returns as the dependent variables and crash events. Panel A displays the results with only the prior year returns dummies, while Panel B reports the results with the control variables and fixed effects from Table 3. For these tests, we estimate the following econometric specification:

$$
r_{t+s, t+s+k}=\sum_{i} \beta_{i} I\left(r_{t-11, t} \in\left[\tau_{i_{1}}, \tau_{i_{2}}\right)\right)+\sum_{j} \psi_{j} z_{t, j}+F E+\xi_{t}
$$

Specifically, we examine future market returns using five different specifications. Annualized future market returns are reported at the annualized 12-month, 24-month and 36-month horizons (models 1,2 and 3), as well as with successive 12-month intervals broken out (models 4 and 5).

\footnotetext{
${ }^{8}$ We also consider whether the inclusion of the United States and United Kingdom in the sample has any influence on the results. In untabulated results, we find that the effects are not sensitive to dropping these countries from the sample.
} 
The prior year return indicator variables, $I\left(r_{t-11, t} \in\left[\tau_{i_{1}}, \tau_{i_{2}}\right)\right)$, are constructed in the same way as equation (1).

In Panels A and B, Model (1) shows that a negative return in the prior year of up to $-10 \%$ is associated with a $-5.6 \%$ to $-6.2 \%$ lower return than for periods when the market had a positive return in the prior year. A negative return of $-50 \%$ or more in the prior year is associated with a $14.0 \%$ to $18.4 \%$ higher return. Moreover, the effects of the large drop appear to reverse again in the year after, as shown in Model (2). One interpretation of these returns dynamics is cyclical behavior - for example, persistence at short horizons and reversal at longer horizons. However, the inclusion of three prior years of returns should control for such a regularity. The crash events may be concentrated in particular time periods or countries, generating cross-sectional and temporal dependencies, thus potentially biasing the model estimates. The standard error corrections and the inclusion of the country and date fixed effects address those issues. 
Thus far, the results consistently demonstrate two patterns. First, markets experiencing a large crash of $-50 \%$ or more have a high probability of a rebound, and the average return following such a crash is nearly $14 \%$ higher than returns with a positive return in the prior year. Second, market declines of up to $-40 \%$ are more likely to be followed by another decline, and the magnitude of this decline is approximately $6 \%$ to $9 \%$ in the following 12 months. In short, above and beyond mean reversion patterns in stock returns, a small decline in a market leads to a much larger drop, and a large drop precedes a large rebound.

\section{Potential Explanations}

\subsection{Institutional explanations}

In this section, we evaluate hypotheses that may explain the results in the previous section. Under specific assumptions, institutional explanations would predict differences in market rebounds, depending on whether a crash is widespread across markets as opposed to a solitary event. A crash that coincides with a world-wide decline in stock markets is more likely to be associated with distress to financial institutions and arbitrageurs because collateral values broadly decline. This would imply that the rebound should be greater when a crash coincides with an average, global market decline.

More generally, a crash coinciding with a global market decline is more likely to be associated with exposure to a systematic, priced risk factor. Such a factor could be based on institutional fragility. Under the assumption that all markets have at least some positive exposure to a global market factor we would expect that a risk-premium based explanation for the documented market dynamics would predict the effects to be stronger when we condition on the factor realization or anticipation of an adverse realization. This is particularly relevant to the 
Berkman et al. (2011) time-varying disaster risk hypothesis. They find that a global index of disaster risk is a cross-sectional and time series predictor of global market returns. This implies that conditioning on a global market decline should predict a larger rebound in the period following a crash.

To test this, we estimate equation (2) for two subsets: crashes that occurred when global market returns are low versus high. Specifically, we calculate the average returns for all countries in the months $t-11$ to $t$, and separate the sample depending on whether the average return of all other countries is below (Low) or above (High) the sample median. The results are reported in Table 5. Models (1) and (4) show the results for the 12 months following a crash when the average global return is coded as Low and High, respectively. The coefficient on the $-50 \%$ crash in Model (1) is positive and significant at the $10 \%$ level, and is comparable to estimates in Table 4 . The results are similar for Model (4), or when average global returns are coded as High. It is also positive and significant (at the 10\% level) and larger in magnitude than the coefficient in Model (1). However, the difference between them are not statistically significant. Thus, the results are not consistent with the prediction implied by the institutional explanations.

In short, conditioning on a widespread decline does not strengthen the rebound effect, and so does not appear to explain the main results. One caveat is that our tests rely on strong assumptions, chief of which is an integrated global capital market - an assumption which is probably only true for some time periods and some countries. Moreover, the results do not support theories that posit a common risk factor as a driver of the documented regularities, although it does not rule them out.

\subsection{Macroeconomic explanations}


As noted above, macroeconomic explanations attribute asset price dynamics to changes in expected returns and discount rates driven by fundamental variables such as conditions affecting profits, risk and risk premia. Our sample of 101 markets lacks comprehensive macroeconomic data and valuation ratios. In order to consider macroeconomic variables and other factors, we restrict our attention to a subset of markets for which we have these variables. We use a dummy associated with depressions, the one-year changes in real GDP, the one-year changes in a consumer price index, a dummy associated with financial crises, the one-year change in loans to nonfinancial private sector-to-GDP ratio, and the dividend yield for 14 markets. ${ }^{9}$ We obtain the data from Barro and Ursúa (2008), Barro and Ursúa (2017), and Jordà, Schularick and Taylor (2017), and the sample years of the merged data is from 1870 to 2008 . This subsample differs markedly from the larger GFD database in focusing on major markets.

Table 6 reports the results of models estimated on the sample subset for which the macroeconomic variables are available. Models (1), (2), and (3) exclude the macroeconomic variables while Models (4), (5) and (6) include them. Note that the influence of a prior year crash is significantly different on this subsample of 14 markets, regardless of whether the additional control variables are included. The negative association between a modest crash and subsequent returns is somewhat smaller in absolute magnitude, suggesting that these effects are stronger in smaller markets - despite our country fixed effect controls. The rebound effect for large crashes is highly significant in this subsample, however. As before, the results reverse over the subsequent year for the available sample.

The effects are similar for the subsample without (Model (1)) and with (Model (4)) the macroeconomic controls. The macroeconomic controls are significant determinants of market

\footnotetext{
${ }^{9}$ In untabulated results, we find that the effects are not sensitive to the inclusion of short-term and long-term interest rates.
} 
returns in the following year. Depressions, inflation, and financial crises are associated with lower subsequent returns. Changes in the GDP are statistically insignificant in Model (4), though become significant in Models (5) and (6), possibly due to collinearity with the depression dummy. Changes in the loan-to-GDP ratio and the dividend yield is associated with higher subsequent returns. If the market rebound pattern is explained by macroeconomic conditions, we expect the coefficient on a large crash to be attenuated with the introduction on these additional factors. The table shows that it is not.

\subsection{Political conflicts}

Political conflicts may coincide with significant macroeconomic events and stock market downturns. Notably, Berkman, Jacobsen and Lee (2011) document that market returns are generally negative at the start and during political conflicts. In years in which political conflicts

end, market returns are generally positive, though not statistically significantly so. It is possible that the stock market crashes used in our tests may be associated with political conflicts, and that the reversal in the following year may be driven by the conclusion of these conflicts. This may explain why the tests in Table 6 show stronger results, given that these countries are more likely to have witnessed resolution in their conflicts, while the countries not included may have been less likely, for a given sample period.

To assess whether political conflicts are driving the results, data from the Internal Crisis Behavior project $[\mathrm{ICB}]$ is used to construct dummies corresponding with the start, middle and end of political conflicts for the sample countries. The database includes information on more than 400 international political conflicts. Given that the database only covers conflicts from 1918 to 2013, the sample is restricted to this time period. 
Table 7 shows the results. Models (1), (2) and (3) include the conflict dummies. Models (4), (5), and (6) also include the macroeconomic variables from Table 6 for the subsample where they are available. The results for the $-50 \%$ crash events are quite similar to the other tables, regardless of whether the macroeconomic variables are included. The coefficients on the middleof-the-conflict dummies are generally negative and statistically significant for some of the specifications. This is consistent with the results in Berkman et al. (2011). However, the coefficients on the start- and end-of-the-conflict dummies are generally positive, but statistically significant only for the start-of-the-conflict dummies.

\subsection{Survival bias}

As discussed above, evidence of a sharp rebound after a major crash in asset prices raises the natural question of whether the data series is conditioned on survival. This may occur because of backfill bias which conditions on current existence, "look-back" bias which conditions on survival, or survival bias that conditions on existence of a succeeding period of observation. One approach to the backfill problem is to identify markets known at the time to exist and to follow them forward.

The JG series that extend from 1920 to 1996 are not retrospectively constructed. They are hand-collected from League of Nations, United Nations bulletins and International Financial Corporation [IFC] publications. This process minimizes potential survival bias because it is possible to "follow-forward" series that were identified as existing national stock markets at the time. We augment the JG data with annual real returns over the period 1900 to 1919 using data for total real returns from Dimson, Marsh and Staunton [DMS] (cf. Dimson, Marsh \& Staunton, 2017). We extend the series from 1997 with DMS and annual real capital appreciation returns 
from MSCI series' in dollar-denominated terms via the Morningstar Direct product. Finally we add Saint-Petersburg Stock Exchange returns over the period 1900 to 1914 and Shanghai Stock Exchange returns over the period 1900 to $1940 .{ }^{10}$

The returns distribution for the data are similar to that described in Table 1 (untabulated). Following years with negative returns $-50 \%$ or more, the likelihood that the market return will be positive is $71.64 \%$, which is larger than similar calculations for the GFD sample. In comparison, the likelihood that the market return will be positive is $58.65 \%$ following years with negative returns.

Table 8 reports the results of estimating our main set of regressions from Table 3 on the smaller, annual dataset. Models (1) through (3) display the results with only the crash dummy terms. Models (4) through (6) display the results including controls for past returns on the past annual returns for years $\mathrm{t}, \mathrm{t}-1$ and $\mathrm{t}-2$, as well as fixed effects on the country and year levels. ${ }^{11}$ They also include the macroeconomic control variables from Table 6. As before, inclusion of the macroeconomic control variables attenuates the sample significantly. The results are not sensitive to including only the past returns variables and the fixed effects for which sample attenuation is less pronounced.

The results show that the reversal effect after a major crash of $-50 \%$ or more is highly significant, similar to the results in Table 4. The magnitudes are relatively larger, and are significant for two years following the crash. When including the controls and fixed effects, the results are stronger despite of the smaller sample size. These findings suggest that the results are unlikely to be driven by potential survivorship biases.

\footnotetext{
${ }^{10}$ The JG, St. Petersburg and Shanghai data is available at http: //viking . som . yale . edu.

${ }^{11}$ Returns volatility for a specific year cannot be calculated using the annual data, which is why only past returns and the fixed effects are included as controls.
} 


\section{Conclusion}

In this paper, we document the performance of global stock markets after crashes of various magnitudes. Of particular interest is whether a rebound after a large crash - a "negative bubble" is likely. Using a large sample of 101 global stock market indexes extending over four centuries and encompassing most of the world's identified stock markets, we find several things. First, crashes of great magnitude are rare. Despite their rarity, they are potentially interesting. A decline in asset values by one-half is frightening to investors, disruptive to the financial system and may indicate a major change in market expectations about future returns and risks. It may even represent an existential risk to the market. Investors are rightly concerned with major crashes, although they typically overestimate the probability of one (cf. Goetzmann, Kim \& Shiller, 2017).

We find an interesting - perhaps comforting - regularity. The probability of a large positive return is higher following a decline in the market of at least $-50 \%$. Returns following a severe crash are on average more than $10 \%$ higher than those following a market gain. We also find some evidence in our broad sample that more modest crashes exhibit the opposite dynamic. Declines on the order of $-10 \%$ to $-20 \%$ are more likely to be followed by another decline. This pattern is not consistent in the data and is not present in a subsample of 41 major markets that does not include many of the markets that appeared since the mid-1990's.

Explaining these dynamics is challenging. We perform a number of tests to differentiate among some prevailing, persuasive theories. We find little support for explanations involving a global factor premium. Estimation confined to crashes correlated to the global market return attenuates rather than strengthens the rebound effect. We likewise find little support for macroeconomic explanations, although we are limited by sample and availability. The pattern of 
negative bubbles may simply be an artifact of sample selection bias. A test on a relatively biasfree subsample suggests it is not. Finally, our findings are also consistent with behavioral theories. Investor pessimism or exuberance could generally manifest as mean reversion, but in the extreme might appear as a positive or negative bubble (cf. Shiller, 2000). Our paper does not directly assess this explanation, though is a promising avenue of future research. 


\section{References}

Ang, A., Goyal, A. and Ilmanen, A., 2014. Asset allocation and bad habits. Rotman International Journal of Pension Management, 7(2), pp.16-27.

Barro, R.J. and Ursúa, J.F., 2008. Macroeconomic Crises since 1870. Brookings Papers on Economic Activity Spring, pp. 255-335.

Barro, R.J. and Ursúa, J.F., 2017. Stock-market crashes and depressions. Research in Economics, 71(3), pp. 384-398.

Berkman, H., Jacobsen, B. and Lee, J.B., 2011. Time-varying rare disaster risk and stock returns. Journal of Financial Economics, 101(2), pp.313-332.

Bialkowski, J.P. and Ronn, E.I., 2016. Financial Markets in the Face of the Apocalypse.

Unpublished manuscript.

Brunnermeier, M.K. and Pedersen, L.H., 2008. Market liquidity and funding liquidity. The review of financial studies, 22(6), pp.2201-2238.

Brunnermeier, Markus K., and Yuliy Sannikov, 2014. A Macroeconomic Model with a Financial Sector. American Economic Review, 104(2), pp.379-421.

Coval, J. and Stafford, E., 2007. Asset fire sales (and purchases) in equity markets. Journal of Financial Economics, 86(2), pp.479-512.

Dimson, E., Marsh, P., Staunton, M., Holland, D.A., Matthews, B.A. and Rath, P., 2017. Credit Suisse Global Investment Returns Yearbook 2017. Credit Suisse.

Driscoll, J.C. and Kraay, A.C., 1998. Consistent covariance matrix estimation with spatially dependent panel data. The Review of Economics and Statistics, 80(4), pp.549-560.

Geanakoplos, John, 2010. The Leverage Cycle. NBER Macroeconomics Annual, 24(1), pp.1-66.

Gromb, D. and Vayanos, D., 2009. Financially constrained arbitrage and cross-market contagion. Working Paper, London School of Economics.

Goetzmann, W.N., Kim, D. and Shiller, R.J., 2017. Crash beliefs from investor surveys (No. w22143). National Bureau of Economic Research.

Goetzmann, W.N., Li, L. and Rouwenhorst, K.G., 2005. Long-Term Global Market Correlations. The Journal of Business, 78(1), pp.1-38.

Hellevik, O., 2009. Linear versus logistic regression when the dependent variable is a dichotomy. Quality \& Quantity, 43(1), pp.59-74.

Jones, B., 2016. Institutionalizing Countercyclical Investment: A Framework for Long-term Asset Owners. IMF Working Papers, 16/38.

Jordà, Ò., Schularick, M., and Taylor, A. 2017. Macrofinancial History and the New Business Cycle Facts. NBER Macroeconomics Annual 2016, 31(1), pp. 213-263. 
Jorion, P. and Goetzmann, W.N., 1999. Global stock markets in the twentieth century. The Journal of Finance, 54(3), pp.953-980.

Moskowitz, T.J., Ooi, Y.H. and Pedersen, L.H., 2012. Time series momentum. Journal of Financial Economics, 104(2), pp.228-250.

Muir, T., 2017. Financial crises and risk premia. The Quarterly Journal of Economics, 132(2), pp.765-809.

Richardson, S., Saffi, P.A. and Sigurdsson, K., 2017. Deleveraging risk. Journal of Financial and Quantitative Analysis, 52(6), pp.2491-2522.

Seyhun, H.N., 1990. Overreaction or fundamentals: Some lessons from insiders' response to the market crash of 1987. The Journal of Finance, 45(5), pp.1363-1388.

Shiller, R.J., 2000. Irrational exuberance. Princeton, New Jersey, Princeon University.

Taylor, Bryan. 2005. GFD Guide to Total Returns on Stocks, Bonds and Bills. Global Financial Data. Inc., ht tp : //WWW. globalfindata . com. 


\section{Figure 1: Number of Markets Represented in Global Financial Database over Time}

This figure presents the number of markets represented in the Global Financial Data sample over time. The $\mathrm{x}$-axis denotes the sample year. The y-axis denotes the number of market as of December for that year.

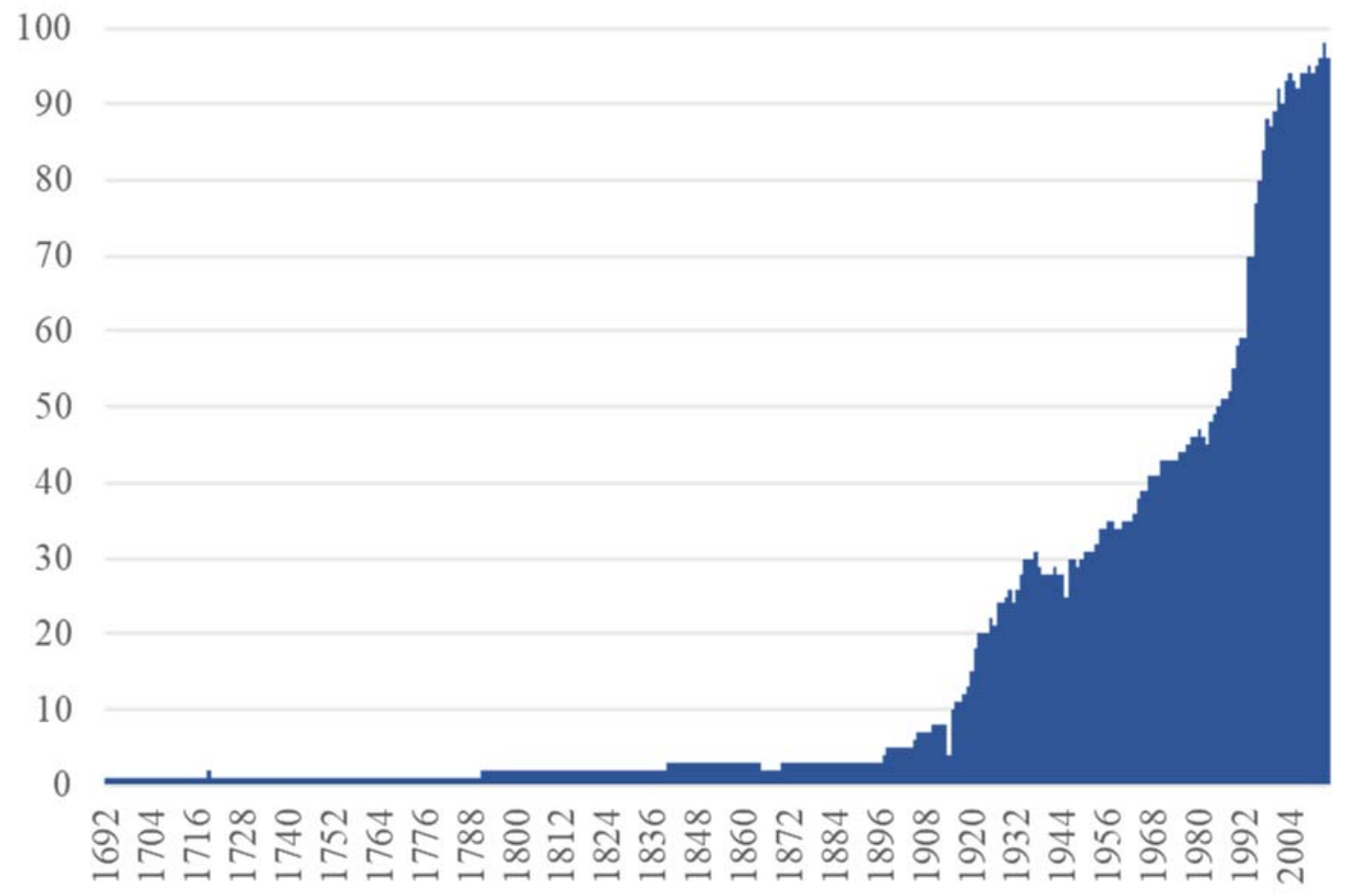




\section{Table 1: Returns Distribution Conditional on Past Returns}

This table presents variable descriptions and summary statistics of the key variables used in the analysis. The variables are collected from the Global Financial Database (GFD); Barro and Ursúa (2008) and Barro and Ursúa (2017) (BU); Jordà, Schularick, and Taylor (2017) (JST); and the International Crisis Behavior data sets (ICB). The summary statistics display the mean, standard deviation, $25^{\text {th }}$ sample percentile, median and $75^{\text {th }}$ sample percentile for the sample where the variable is available.

\begin{tabular}{|c|c|c|}
\hline \multicolumn{3}{|c|}{ Panel A: Variable Descriptions } \\
\hline Variable Name & Description & Source \\
\hline $\mathrm{R}_{\mathrm{t} 1, \mathrm{t} 2}$ & Annualized real returns for the market from months $t 1$ to $t 2$. & GFD \\
\hline $\mathrm{I}\left(\mathrm{x} \%>\mathrm{R}_{\mathrm{t} 1, \mathrm{t} 2} \geq \mathrm{y} \%\right)$ & $\begin{array}{l}\text { Dummy that takes value } 1 \text { if the real return for the market from months } t 1 \text { to } t 2 \text { is } \\
\text { between } x \% \text { and } y \% \text {, and zero otherwise. }\end{array}$ & GFD \\
\hline$\sigma_{\mathrm{t} 1, \mathrm{t} 2}$ & Volatility based upon monthly real returns for the market from months $\mathrm{t} 1$ to $\mathrm{t} 2$. & GFD \\
\hline Change in $\sigma_{\mathrm{t} 1, \mathrm{t} 2}$ & Change in real returns volatility for the market from months $t 1$ to $t 2$. & GFD \\
\hline Depression $_{t}$ & Dummy that takes value 1 if the market is experiencing a depression on months $t$. & BU \\
\hline Change in Real GDP $\mathrm{t}_{\mathrm{t} 1, \mathrm{t} 2}$ & Real GDP percentage for the market change from months $t 1$ to $t 2$. & BU \\
\hline Change in $\mathrm{CPI}_{\mathrm{t} 1, \mathrm{t} 2}$ & Consumer price index percentage change for the market from months $t 1$ to $t 2$. & JST \\
\hline Financial Crisist & $\begin{array}{l}\text { Dummy that takes value } 1 \text { if the market is experiencing a systemic financial crisis } \\
\text { on month } t \text {, and zero otherwise. }\end{array}$ & JST \\
\hline Change in $(\text { Loan/GDP })_{\mathrm{t} 1, \mathrm{t} 2}$ & $\begin{array}{l}\text { Change in the loan to non-financial private sector-to-GDP ratio for the market } \\
\text { from months t } 1 \text { to } 2 \text {. }\end{array}$ & JST \\
\hline$(\mathrm{D} / \mathrm{P})_{\mathrm{t}}$ & Dividend yield for the market on month $\mathrm{t}$. & GFD \\
\hline Start of Conflictt1,t2 & $\begin{array}{l}\text { Dummy that takes value } 1 \text { if the the start of a political conflict for the market } \\
\text { occurs between months } t 1 \text { to } 2 \text {, and zero otherwise. }\end{array}$ & ICB \\
\hline Middle of Conflict $t 1, t 2$ & $\begin{array}{l}\text { Dummy that takes value } 1 \text { if the the middle of a political conflict for the market } \\
\text { occurs between months } t 1 \text { to } 2 \text {, and zero otherwise. }\end{array}$ & ICB \\
\hline End of Conflict $t 1, t 2$ & $\begin{array}{l}\text { Dummy that takes value } 1 \text { if the the end of a political conflict for the market } \\
\text { occurs between months t } 1 \text { to } 2 \text {, and zero otherwise. }\end{array}$ & ICB \\
\hline
\end{tabular}

\begin{tabular}{|c|c|c|c|c|c|c|}
\hline \multicolumn{7}{|c|}{ Panel B: Summary Statistics } \\
\hline Variable Name & $\mathbf{N}$ & Mean & $\begin{array}{l}\text { Standard } \\
\text { Deviation }\end{array}$ & $\begin{array}{c}2^{\text {th }} \\
\text { Percentile }\end{array}$ & Median & $\begin{array}{c}{75^{\text {th }}}^{\text {Percentile }} \\
\end{array}$ \\
\hline $\mathrm{R}_{\mathrm{t}+1, \mathrm{t}+12}$ & 58442 & 0.0561 & 0.3579 & -0.1212 & 0.0110 & 0.1714 \\
\hline $\mathrm{R}_{\mathrm{t}+1, \mathrm{t}+24}$ & 58442 & 0.0333 & 0.2295 & -0.0920 & 0.0080 & 0.1312 \\
\hline $\mathrm{R}_{\mathrm{t}+1, \mathrm{t}+36}$ & 58442 & 0.0251 & 0.1829 & -0.0738 & 0.0086 & 0.1053 \\
\hline $\mathrm{R}_{\mathrm{t}-11, \mathrm{t}}$ & 58442 & 0.0588 & 0.3600 & -0.1229 & 0.0140 & 0.1769 \\
\hline $\mathrm{I}\left(0 \%>\mathrm{R}_{\mathrm{t}-11, \mathrm{t}} \geq-10 \%\right)$ & 58442 & 0.1854 & 0.3886 & 0.0000 & 0.0000 & 0.0000 \\
\hline $\mathrm{I}\left(-10 \%>\mathrm{R}_{\mathrm{t}-11, \mathrm{t}} \geq-20 \%\right)$ & 58442 & 0.1350 & 0.3418 & 0.0000 & 0.0000 & 0.0000 \\
\hline $\mathrm{I}\left(-20 \%>\mathrm{R}_{\mathrm{t}-11, \mathrm{t}} \geq-30 \%\right)$ & 58442 & 0.0776 & 0.2675 & 0.0000 & 0.0000 & 0.0000 \\
\hline $\mathrm{I}\left(-30 \%>\mathrm{R}_{\mathrm{t}-11, \mathrm{t}} \geq-40 \%\right)$ & 58442 & 0.0378 & 0.1908 & 0.0000 & 0.0000 & 0.0000 \\
\hline $\mathrm{I}\left(-40 \%>\mathrm{R}_{\mathrm{t}-11, \mathrm{t}} \geq-50 \%\right)$ & 58442 & 0.0176 & 0.1316 & 0.0000 & 0.0000 & 0.0000 \\
\hline $\mathrm{I}\left(-50 \%>\mathrm{R}_{\mathrm{t}-11, \mathrm{t}} \geq-100 \%\right)$ & 58442 & 0.0185 & 0.1349 & 0.0000 & 0.0000 & 0.0000 \\
\hline$\sigma_{\mathrm{t}-11, \mathrm{t}}$ & 58442 & 0.0544 & 0.0423 & 0.0282 & 0.0431 & 0.0666 \\
\hline Change in $\sigma_{t-11, t}$ & 58442 & -0.0006 & 0.0373 & -0.0143 & -0.0004 & 0.0128 \\
\hline Depression $_{t}$ & 10765 & 0.0547 & 0.2274 & 0.0000 & 0.0000 & 0.0000 \\
\hline Change in Real GDP ${ }_{t-11, t}$ & 10765 & 0.0251 & 0.0322 & 0.0087 & 0.0253 & 0.0418 \\
\hline Change in $\mathrm{CPI}_{\mathrm{t}-11, \mathrm{t}}$ & 10765 & 0.0395 & 0.0602 & 0.0121 & 0.0283 & 0.0604 \\
\hline Financial Crisist & 10765 & 0.0397 & 0.1952 & 0.0000 & 0.0000 & 0.0000 \\
\hline Change in $(\text { Loan/GDP })_{t-11, t}$ & 10765 & 0.0108 & 0.0386 & -0.0057 & 0.0075 & 0.0269 \\
\hline$(\mathrm{D} / \mathrm{P})_{\mathrm{t}}$ & 10765 & 1.2760 & 0.4921 & 1.0296 & 1.3558 & 1.5913 \\
\hline Start of Conflict $-11, \mathrm{t}$ & 50834 & 0.0071 & 0.0840 & 0.0000 & 0.0000 & 0.0000 \\
\hline Middle of Conflict $\mathrm{t}-11, \mathrm{t}$ & 50834 & 0.1502 & 0.3573 & 0.0000 & 0.0000 & 0.0000 \\
\hline End of Conflict $-11, \mathrm{t}$ & 50834 & 0.0054 & 0.0736 & 0.0000 & 0.0000 & 0.0000 \\
\hline
\end{tabular}




\section{Table 2: Conditional Returns Distributions Based Upon Past Extreme Returns}

This table presents the percentage of observations where the cumulative, 1 -year return from months $t+1$ to $t+12$ is within ranges indicated in the first row. The rows indicate subsamples based upon whether the cumulative return from months $\mathrm{t}-11$ to $\mathrm{t}$ is up to threshold $x$, where $x \in\{0 \%,-10 \%,-20 \%,-30 \%,-40 \%,-50 \%\}$.

\begin{tabular}{|c|c|c|c|c|c|c|c|c|c|c|}
\hline $\begin{array}{l}\text { Returns } t+1, t+12 \\
\text { Dummy } \\
\text { Specification: }\end{array}$ & $\mathrm{N}$ & $\begin{array}{c}{[-100 \%,} \\
-50 \%)\end{array}$ & $\begin{array}{c}{[-100 \%} \\
-25 \%) \\
\end{array}$ & $\begin{array}{c}{[-100 \%} \\
-10 \%) \\
\end{array}$ & $\begin{array}{c}{[-100 \%} \\
0 \%)\end{array}$ & $\begin{array}{c}(0 \%, \\
+\infty)\end{array}$ & $\begin{array}{c}(+10 \% \\
+\infty)\end{array}$ & $\begin{array}{c}(+25 \% \\
+\infty)\end{array}$ & $\begin{array}{c}(+50 \% \\
+\infty)\end{array}$ & $\begin{array}{c}(+100 \% \\
+\infty)\end{array}$ \\
\hline $\mathrm{R}_{\mathrm{t}-11, \mathrm{t}}<0 \%$ & 26681 & $1.8 \%$ & $11.3 \%$ & $31.6 \%$ & $52.4 \%$ & $47.3 \%$ & $30.1 \%$ & $15.1 \%$ & $5.8 \%$ & $1.4 \%$ \\
\hline $\mathrm{R}_{\mathrm{t}-11, \mathrm{t}}<-10 \%$ & 16190 & $2.3 \%$ & $14.0 \%$ & $34.5 \%$ & $52.9 \%$ & $46.9 \%$ & $31.5 \%$ & $17.1 \%$ & $6.9 \%$ & $1.7 \%$ \\
\hline $\mathrm{R}_{\mathrm{t}-11, \mathrm{t}}<-20 \%$ & 8549 & $3.1 \%$ & $16.6 \%$ & $36.2 \%$ & $51.7 \%$ & $48.1 \%$ & $35.0 \%$ & $21.2 \%$ & $9.3 \%$ & $2.2 \%$ \\
\hline $\mathrm{R}_{\mathrm{t}-11, \mathrm{t}}<-30 \%$ & 4170 & $4.5 \%$ & $18.8 \%$ & $36.4 \%$ & $48.6 \%$ & $51.1 \%$ & $40.6 \%$ & $27.0 \%$ & $13.4 \%$ & $3.4 \%$ \\
\hline $\mathrm{R}_{\mathrm{t}-11, \mathrm{t}}<-40 \%$ & 2030 & $6.4 \%$ & $19.3 \%$ & $34.2 \%$ & $44.1 \%$ & $55.6 \%$ & $47.3 \%$ & $34.9 \%$ & $19.3 \%$ & $5.9 \%$ \\
\hline $\mathrm{R}_{\mathrm{t}-11, \mathrm{t}}<-50 \%$ & 1032 & $9.3 \%$ & $21.6 \%$ & $32.8 \%$ & $40.2 \%$ & $59.4 \%$ & $51.7 \%$ & $40.6 \%$ & $25.5 \%$ & $9.6 \%$ \\
\hline
\end{tabular}




\section{Table 3: Conditional Returns Distribution Regressions}

This table presents estimates of Equation (1). The dependent variables are dummies based upon whether the cumulative, 1 -year return from months $t+1$ to $t+12$ is above or below the thresholds specified in the first row. $I\left(t 1>R_{t-11, t} \geq t 2\right)$ is a dummy variable based upon whether the cumulative return from month $t-11$ to $t$ is below $t 1$ but at least $t 2$. Panel A (Panel B) reports the results without (with) the control variables and fixed effects terms. Control variables included where indicated, but not reported, are returns volatility over months $t-11$ to $t$; change in returns volatility between months $t-11$ to $t$ and $t-23$ to $t-12$; cumulative returns from months $\mathrm{t}-11$ to $\mathrm{t}$; cumulative returns from $\mathrm{t}-23$ to $\mathrm{t}-12$; and cumulative returns from $\mathrm{t}-35$ to $\mathrm{t}-24$. Country and date fixed effects are included where indicated, but not reported. Robust standard errors based upon Driscoll and Kraay (1998) estimators are used to calculate $t$-statistics (in parentheses). Statistical significance at the $10 \%, 5 \%$ and $1 \%$ levels are denoted by $* * *$, and $* * *$, respectively.

\begin{tabular}{|c|c|c|c|c|c|c|c|c|}
\hline \multicolumn{9}{|c|}{ Panel A: Without Controls } \\
\hline $\begin{array}{l}\text { Model: } \\
\text { Returns } \mathrm{t}+1, \mathrm{t}+12 \text { Dummy Specification: }\end{array}$ & $\begin{array}{c}(1) \\
{[-100 \%} \\
-50 \%) \\
\end{array}$ & $\begin{array}{c}(2) \\
{[-100 \%} \\
-25 \%) \\
\end{array}$ & $\begin{array}{c}(3) \\
{[-100 \%} \\
-10 \%) \\
\end{array}$ & $\begin{array}{c}(4) \\
{[-100 \%} \\
0 \%) \\
\end{array}$ & $\begin{array}{l}(5) \\
(0 \% \\
+\infty) \\
\end{array}$ & $\begin{array}{l}(6) \\
+10 \% \\
+\infty) \\
\end{array}$ & $\begin{array}{l}(7) \\
(+25 \% \\
+\infty) \\
\end{array}$ & $\begin{array}{l}(8) \\
(+50 \% \\
+\infty) \\
\end{array}$ \\
\hline $\mathrm{I}\left(0 \%>\mathrm{R}_{\mathrm{t}-11, \mathrm{t}} \geq-10 \%\right)$ & $\begin{array}{c}-0.008 * * \\
(-2.05)\end{array}$ & $\begin{array}{c}-0.023 * * \\
(-2.54)\end{array}$ & $\begin{array}{l}0.018 \\
(1.30)\end{array}$ & $\begin{array}{l}0.089 * * * \\
(5.31)\end{array}$ & $\begin{array}{c}-0.089 * * * \\
(-5.32)\end{array}$ & $\begin{array}{c}-0.097 * * * \\
(-6.01)\end{array}$ & $\begin{array}{c}-0.075 * * * \\
(-6.72)\end{array}$ & $\begin{array}{c}-0.032 * * * \\
(-6.32)\end{array}$ \\
\hline $\mathrm{I}\left(-10 \%>\mathrm{R}_{\mathrm{t}-11, \mathrm{t}} \geq-20 \%\right)$ & $\begin{array}{l}-0.004 \\
(-1.03)\end{array}$ & $\begin{array}{l}0.014 \\
(1.15)\end{array}$ & $\begin{array}{c}0.074 * * * \\
(3.84)\end{array}$ & $\begin{array}{l}0.111 * * * \\
(5.16)\end{array}$ & $\begin{array}{c}-0.111 * * * \\
(-5.17)\end{array}$ & $\begin{array}{c}-0.100 * * * \\
(-5.07)\end{array}$ & $\begin{array}{c}-0.067 * * * \\
(-4.83)\end{array}$ & $\begin{array}{c}-0.032 * * * \\
(-5.54)\end{array}$ \\
\hline $\mathrm{I}\left(-20 \%>\mathrm{R}_{\mathrm{t}-11, \mathrm{t}} \geq-30 \%\right)$ & $\begin{array}{l}0.000 \\
(0.09)\end{array}$ & $\begin{array}{l}0.050 * * * \\
(3.34)\end{array}$ & $\begin{array}{l}0.109 * * * \\
(4.67)\end{array}$ & $\begin{array}{l}0.119 * * * \\
\quad(4.76)\end{array}$ & $\begin{array}{c}-0.119 * * * \\
(-4.77)\end{array}$ & $\begin{array}{c}-0.081 * * * \\
(-3.38)\end{array}$ & $\begin{array}{c}-0.040 * * \\
(-2.44)\end{array}$ & $\begin{array}{c}-0.018 * * * \\
(-2.60)\end{array}$ \\
\hline$I\left(-30 \%>R_{t-11, t} \geq-40 \%\right)$ & $\begin{array}{l}0.008 \\
(1.36)\end{array}$ & $\begin{array}{c}0.084 * * * \\
(4.28)\end{array}$ & $\begin{array}{c}0.130 * * * \\
(4.35)\end{array}$ & $\begin{array}{l}0.099 * * * \\
(3.10)\end{array}$ & $\begin{array}{c}-0.099 * * * \\
(-3.11)\end{array}$ & $\begin{array}{l}-0.033 \\
(-1.02)\end{array}$ & $\begin{array}{l}-0.000 \\
(-0.02)\end{array}$ & $\begin{array}{l}0.004 \\
(0.37)\end{array}$ \\
\hline $\mathrm{I}\left(-40 \%>\mathrm{R}_{\mathrm{t}-11, \mathrm{t}} \geq-50 \%\right)$ & $\begin{array}{l}0.015 \\
(1.55)\end{array}$ & $\begin{array}{c}0.074 * * * \\
(2.60)\end{array}$ & $\begin{array}{c}0.102 * * \\
(2.15)\end{array}$ & $\begin{array}{l}0.053 \\
(0.97)\end{array}$ & $\begin{array}{l}-0.053 \\
(-0.97)\end{array}$ & $\begin{array}{l}0.048 \\
(0.86)\end{array}$ & $\begin{array}{l}0.093^{*} \\
(1.79)\end{array}$ & $\begin{array}{c}0.055^{* *} \\
(2.36)\end{array}$ \\
\hline $\mathrm{I}\left(-50 \%>\mathrm{R}_{\mathrm{t}-11, \mathrm{t}} \geq-100 \%\right)$ & $\begin{array}{c}0.072 * * * \\
(2.87)\end{array}$ & $\begin{array}{c}0.127 * * * \\
(2.60)\end{array}$ & $\begin{array}{l}0.085 \\
(1.40)\end{array}$ & $\begin{array}{l}-0.017 \\
(-0.26)\end{array}$ & $\begin{array}{l}0.017 \\
(0.26)\end{array}$ & $\begin{array}{c}0.134^{*} \\
(1.93)\end{array}$ & $\begin{array}{c}0.204 * * * \\
(3.34)\end{array}$ & $\begin{array}{c}0.178^{* * *} \\
(4.97)\end{array}$ \\
\hline $\begin{array}{l}\text { Control Variables } \\
\text { Country and Date FEs }\end{array}$ & $\begin{array}{l}\mathrm{NO} \\
\mathrm{NO}\end{array}$ & $\begin{array}{l}\mathrm{NO} \\
\mathrm{NO}\end{array}$ & $\begin{array}{l}\mathrm{NO} \\
\mathrm{NO}\end{array}$ & $\begin{array}{l}\mathrm{NO} \\
\mathrm{NO}\end{array}$ & $\begin{array}{l}\mathrm{NO} \\
\mathrm{NO}\end{array}$ & $\begin{array}{l}\text { NO } \\
\text { NO }\end{array}$ & $\begin{array}{l}\mathrm{NO} \\
\mathrm{NO}\end{array}$ & $\begin{array}{l}\mathrm{NO} \\
\mathrm{NO}\end{array}$ \\
\hline $\begin{array}{l}\mathrm{N} \\
\text { Adjusted } \mathrm{R}^{2}\end{array}$ & $\begin{array}{l}58442 \\
0.70 \%\end{array}$ & $\begin{array}{l}58442 \\
0.95 \%\end{array}$ & $\begin{array}{l}58442 \\
0.85 \%\end{array}$ & $\begin{array}{l}58442 \\
1.06 \%\end{array}$ & $\begin{array}{l}58442 \\
1.07 \%\end{array}$ & $\begin{array}{l}58442 \\
1.26 \%\end{array}$ & $\begin{array}{l}58442 \\
1.65 \%\end{array}$ & $\begin{array}{l}58442 \\
1.57 \%\end{array}$ \\
\hline
\end{tabular}




\begin{tabular}{|c|c|c|c|c|c|c|c|c|}
\hline \multicolumn{9}{|c|}{ Panel B: With Controls } \\
\hline $\begin{array}{l}\text { Model: } \\
\text { Returns } t+1, t+12 \text { Dummy Specification: }\end{array}$ & $\begin{array}{c}(1) \\
{[-100 \%} \\
-50 \%) \\
\end{array}$ & $\begin{array}{c}(2) \\
{[-100 \%} \\
-25 \%) \\
\end{array}$ & $\begin{array}{c}(3) \\
{[-100 \%} \\
-10 \%) \\
\end{array}$ & $\begin{array}{c}(4) \\
{[-100 \%} \\
0 \%) \\
\end{array}$ & $\begin{array}{l}(5) \\
(0 \% \\
+\infty) \\
\end{array}$ & $\begin{array}{l}(6) \\
+10 \% \\
+\infty)\end{array}$ & $\begin{array}{c}(7) \\
(+25 \% \\
+\infty) \\
\end{array}$ & $\begin{array}{c}(8) \\
(+50 \% \\
+\infty) \\
\end{array}$ \\
\hline $\mathrm{I}\left(0 \%>\mathrm{R}_{\mathrm{t}-11, \mathrm{t}} \geq-10 \%\right)$ & $\begin{array}{c}0.015 * * * \\
(5.37)\end{array}$ & $\begin{array}{c}0.021 * * * \\
(3.46)\end{array}$ & $\begin{array}{c}0.059 * * * \\
(4.86)\end{array}$ & $\begin{array}{c}0.098 * * * \\
(6.43)\end{array}$ & $\begin{array}{c}-0.098 * * * \\
(-6.45)\end{array}$ & $\begin{array}{c}-0.081 * * * \\
(-5.57)\end{array}$ & $\begin{array}{c}-0.053 * * * \\
(-5.58)\end{array}$ & $\begin{array}{c}-0.019 * * * \\
(-4.49)\end{array}$ \\
\hline $\mathrm{I}\left(-10 \%>\mathrm{R}_{\mathrm{t}-11, \mathrm{t}} \geq-20 \%\right)$ & $\begin{array}{c}0.021 * * * \\
(5.08)\end{array}$ & $\begin{array}{c}0.052 * * * \\
(5.15)\end{array}$ & $\begin{array}{c}0.103 * * * \\
(5.87)\end{array}$ & $\begin{array}{c}0.122 * * * \\
(6.06)\end{array}$ & $\begin{array}{c}-0.122 * * * \\
(-6.07)\end{array}$ & $\begin{array}{c}-0.096^{* * *} \\
(-5.25)\end{array}$ & $\begin{array}{c}-0.060 * * * \\
(-4.65)\end{array}$ & $\begin{array}{c}-0.028 * * * \\
(-4.60)\end{array}$ \\
\hline $\mathrm{I}\left(-20 \%>\mathrm{R}_{\mathrm{t}-11, \mathrm{t}} \geq-30 \%\right)$ & $\begin{array}{c}0.023 * * * \\
(4.24)\end{array}$ & $\begin{array}{c}0.067 * * * \\
(5.03)\end{array}$ & $\begin{array}{c}0.125 * * * \\
(5.72)\end{array}$ & $\begin{array}{c}0.134 * * * \\
(5.82)\end{array}$ & $\begin{array}{c}-0.135^{* * * *} \\
(-5.83)\end{array}$ & $\begin{array}{c}-0.095 * * * \\
(-4.34)\end{array}$ & $\begin{array}{c}-0.051 * * * \\
(-3.29)\end{array}$ & $\begin{array}{c}-0.028 * * * \\
(-3.54)\end{array}$ \\
\hline $\mathrm{I}\left(-30 \%>\mathrm{R}_{\mathrm{t}-11, \mathrm{t}} \geq-40 \%\right)$ & $\begin{array}{c}0.030 * * * \\
(4.08)\end{array}$ & $\begin{array}{c}0.079 * * * \\
(4.30)\end{array}$ & $\begin{array}{c}0.133 * * * \\
(4.73)\end{array}$ & $\begin{array}{c}0.113 * * * \\
(3.59)\end{array}$ & $\begin{array}{c}-0.114 * * * \\
(-3.60)\end{array}$ & $\begin{array}{l}-0.060^{*} \\
(-1.81)\end{array}$ & $\begin{array}{l}-0.027 \\
(-1.05)\end{array}$ & $\begin{array}{l}-0.021^{*} \\
(-1.93)\end{array}$ \\
\hline $\mathrm{I}\left(-40 \%>\mathrm{R}_{\mathrm{t}-11, \mathrm{t}} \geq-50 \%\right)$ & $\begin{array}{c}0.027 * * \\
(2.57)\end{array}$ & $\begin{array}{c}0.050^{*} \\
(1.94)\end{array}$ & $\begin{array}{c}0.095 * * \\
(2.16)\end{array}$ & $\begin{array}{l}0.075 \\
(1.37)\end{array}$ & $\begin{array}{l}-0.075 \\
(-1.37)\end{array}$ & $\begin{array}{l}0.001 \\
(0.02)\end{array}$ & $\begin{array}{l}0.044 \\
(0.80)\end{array}$ & $\begin{array}{l}0.017 \\
(0.66)\end{array}$ \\
\hline $\mathrm{I}\left(-50 \%>\mathrm{R}_{\mathrm{t}-11, \mathrm{t}} \geq-100 \%\right)$ & $\begin{array}{c}0.051 * * \\
(2.04)\end{array}$ & $\begin{array}{l}0.041 \\
(0.96)\end{array}$ & $\begin{array}{l}0.019 \\
(0.35)\end{array}$ & $\begin{array}{l}-0.018 \\
(-0.26)\end{array}$ & $\begin{array}{l}0.018 \\
(0.26)\end{array}$ & $\begin{array}{l}0.074 \\
(0.97)\end{array}$ & $\begin{array}{l}0.121^{*} \\
(1.77)\end{array}$ & $\begin{array}{c}0.105^{* * * *} \\
(2.72)\end{array}$ \\
\hline Control Variables & YES & YES & YES & YES & YES & YES & YES & YES \\
\hline Country and Date FEs & YES & YES & YES & YES & YES & YES & YES & YES \\
\hline $\begin{array}{l}\mathrm{N} \\
\text { Adjusted } \mathrm{R}^{2}\end{array}$ & $\begin{array}{c}58442 \\
14.54 \%\end{array}$ & $\begin{array}{c}58442 \\
22.57 \%\end{array}$ & $\begin{array}{c}58442 \\
22.77 \%\end{array}$ & $\begin{array}{c}58442 \\
23.77 \%\end{array}$ & $\begin{array}{c}58442 \\
23.75 \%\end{array}$ & $\begin{array}{c}58442 \\
22.95 \%\end{array}$ & $\begin{array}{c}58442 \\
19.12 \%\end{array}$ & $\begin{array}{c}58442 \\
11.05 \%\end{array}$ \\
\hline
\end{tabular}




\section{Table 4: Returns in Years Following Crash Events}

This table presents estimates of Equation (2). The dependent variables are cumulative return over the interval indicated in the first row. $I\left(t 1>R_{t-11, t} \geq t 2\right)$ is a dummy variable based upon whether the cumulative return from month $t-11$ to $t$ is below $t 1$ but at least $t 2$. Panel A (Panel B) reports the results without (with) the control variables and fixed effects terms. Control variables from Table 3 are included where indicated, but not reported. Country and date fixed effects are included where indicated, but not reported. Robust standard errors based upon Driscoll and Kraay (1998) estimators are used to calculate $t$-statistics (in parentheses). Statistical significance at the $10 \%, 5 \%$ and $1 \%$ levels are denoted by $* * *$, and $* * *$, respectively.

\begin{tabular}{|c|c|c|c|c|c|}
\hline \multicolumn{6}{|c|}{ Panel A: Without Controls } \\
\hline$\frac{\text { Model: }}{\text { Returns Specification: }}$ & $\begin{array}{c}(1) \\
{[\mathrm{t}+1, \mathrm{t}+12]}\end{array}$ & $\begin{array}{c}(2) \\
{[\mathrm{t}+1, \mathrm{t}+24]}\end{array}$ & $\begin{array}{c}(3) \\
{[\mathrm{t}+1, \mathrm{t}+36]} \\
\end{array}$ & $\begin{array}{c}(4) \\
{[\mathrm{t}+13, \mathrm{t}+24]}\end{array}$ & $\begin{array}{c}(5) \\
{[t+25, t+36]}\end{array}$ \\
\hline $\mathrm{I}\left(0 \%>\mathrm{R}_{\mathrm{t}-11, \mathrm{t}} \geq-10 \%\right)$ & $\begin{array}{c}-0.056^{* * *} \\
(-4.95)\end{array}$ & $\begin{array}{c}-0.016^{*} \\
(-1.86)\end{array}$ & $\begin{array}{l}-0.004 \\
(-0.66)\end{array}$ & $\begin{array}{l}0.008 \\
(0.75)\end{array}$ & $\begin{array}{l}0.005 \\
(0.41)\end{array}$ \\
\hline $\mathrm{I}\left(-10 \%>\mathrm{R}_{\mathrm{t}-11, \mathrm{t}} \geq-20 \%\right)$ & $\begin{array}{c}-0.069 * * * \\
(-5.31)\end{array}$ & $\begin{array}{c}-0.021 * * \\
(-2.14)\end{array}$ & $\begin{array}{l}-0.002 \\
(-0.26)\end{array}$ & $\begin{array}{l}0.015 \\
(1.13)\end{array}$ & $\begin{array}{c}0.028^{* *} \\
(1.99)\end{array}$ \\
\hline $\mathrm{I}\left(-20 \%>\mathrm{R}_{\mathrm{t}-11, \mathrm{t}} \geq-30 \%\right)$ & $\begin{array}{c}-0.070 * * * \\
(-4.54)\end{array}$ & $\begin{array}{c}-0.025^{* *} \\
(-2.22)\end{array}$ & $\begin{array}{l}-0.005 \\
(-0.49)\end{array}$ & $\begin{array}{l}0.014 \\
(0.89)\end{array}$ & $\begin{array}{c}0.035^{* *} \\
(2.19)\end{array}$ \\
\hline $\mathrm{I}\left(-30 \%>\mathrm{R}_{\mathrm{t}-11, \mathrm{t}} \geq-40 \%\right)$ & $\begin{array}{c}-0.056^{* * * *} \\
(-2.71)\end{array}$ & $\begin{array}{c}-0.030 * * \\
(-2.03)\end{array}$ & $\begin{array}{l}-0.016 \\
(-1.41)\end{array}$ & $\begin{array}{l}-0.007 \\
(-0.35)\end{array}$ & $\begin{array}{l}0.020 \\
(0.81)\end{array}$ \\
\hline $\mathrm{I}\left(-40 \%>\mathrm{R}_{\mathrm{t}-11, \mathrm{t}} \geq-50 \%\right)$ & $\begin{array}{l}0.006 \\
(0.16)\end{array}$ & $\begin{array}{l}-0.012 \\
(-0.47)\end{array}$ & $\begin{array}{l}-0.012 \\
(-0.85)\end{array}$ & $\begin{array}{l}-0.009 \\
(-0.44)\end{array}$ & $\begin{array}{l}0.011 \\
(0.31)\end{array}$ \\
\hline $\mathrm{I}\left(-50 \%>\mathrm{R}_{\mathrm{t}-11, \mathrm{t}} \geq-100 \%\right)$ & $\begin{array}{l}0.184 * * * \\
\quad(2.70)\end{array}$ & $\begin{array}{l}0.039 \\
(1.01)\end{array}$ & $\begin{array}{l}-0.020 \\
(-0.77)\end{array}$ & $\begin{array}{l}0.021 \\
(0.64)\end{array}$ & $\begin{array}{l}-0.050 \\
(-0.94)\end{array}$ \\
\hline Control Variables & NO & NO & $\mathrm{NO}$ & NO & NO \\
\hline $\begin{array}{l}\mathrm{N} \\
\text { Adjusted } \mathrm{R}^{2}\end{array}$ & $\begin{array}{l}58442 \\
1.47 \%\end{array}$ & $\begin{array}{l}58442 \\
0.49 \%\end{array}$ & $\begin{array}{l}58442 \\
0.11 \%\end{array}$ & $\begin{array}{l}56962 \\
0.04 \%\end{array}$ & $\begin{array}{l}55545 \\
0.17 \%\end{array}$ \\
\hline \multicolumn{6}{|c|}{ Panel B: With Controls } \\
\hline$\frac{\text { Model: }}{\text { Returns Specification: }}$ & $\begin{array}{c}(1) \\
{[\mathrm{t}+1, \mathrm{t}+12]}\end{array}$ & $\begin{array}{c}(2) \\
{[\mathrm{t}+1, \mathrm{t}+24]} \\
\end{array}$ & $\begin{array}{c}(3) \\
{[\mathrm{t}+1, \mathrm{t}+36]}\end{array}$ & $\begin{array}{c}(4) \\
{[\mathrm{t}+13, \mathrm{t}+24]}\end{array}$ & $\begin{array}{c}(5) \\
{[\mathrm{t}+25, \mathrm{t}+36]} \\
\end{array}$ \\
\hline $\mathrm{I}\left(0 \%>\mathrm{R}_{\mathrm{t}-11, \mathrm{t}} \geq-10 \%\right)$ & $\begin{array}{c}-0.062 * * * \\
(-6.84)\end{array}$ & $\begin{array}{c}-0.025 * * * \\
(-3.63)\end{array}$ & $\begin{array}{c}-0.012 * * \\
(-2.41)\end{array}$ & $\begin{array}{c}0.012 \\
(1.15)\end{array}$ & $\begin{array}{r}0.009 \\
(1.05)\end{array}$ \\
\hline $\mathrm{I}\left(-10 \%>\mathrm{R}_{\mathrm{t}-11, \mathrm{t}} \geq-20 \%\right)$ & $\begin{array}{c}-0.083 * * * \\
(-6.95)\end{array}$ & $\begin{array}{c}-0.036 * * * \\
(-3.85)\end{array}$ & $\begin{array}{c}-0.014 * * \\
(-2.16)\end{array}$ & $\begin{array}{l}0.011 \\
(0.78)\end{array}$ & $\begin{array}{c}0.025 * * \\
(2.13)\end{array}$ \\
\hline $\mathrm{I}\left(-20 \%>\mathrm{R}_{\mathrm{t}-11, \mathrm{t}} \geq-30 \%\right)$ & $\begin{array}{c}-0.093 * * * \\
(-6.40)\end{array}$ & $\begin{array}{c}-0.046^{* * *} \\
(-4.14)\end{array}$ & $\begin{array}{c}-0.022 * * * \\
(-2.67)\end{array}$ & $\begin{array}{l}-0.001 \\
(-0.03)\end{array}$ & $\begin{array}{l}0.020 \\
(1.33)\end{array}$ \\
\hline $\mathrm{I}\left(-30 \%>\mathrm{R}_{\mathrm{t}-11, \mathrm{t}} \geq-40 \%\right)$ & $\begin{array}{c}-0.089 * * * \\
(-3.96)\end{array}$ & $\begin{array}{c}-0.057 * * * \\
(-3.53)\end{array}$ & $\begin{array}{c}-0.039 * * * \\
(-3.41)\end{array}$ & $\begin{array}{l}-0.035 \\
(-1.48)\end{array}$ & $\begin{array}{l}-0.011 \\
(-0.54)\end{array}$ \\
\hline $\mathrm{I}\left(-40 \%>\mathrm{R}_{\mathrm{t}-11, \mathrm{t}} \geq-50 \%\right)$ & $\begin{array}{l}-0.034 \\
(-0.84)\end{array}$ & $\begin{array}{l}-0.043 \\
(-1.54)\end{array}$ & $\begin{array}{c}-0.038^{* *} \\
(-2.54)\end{array}$ & $\begin{array}{l}-0.048 * \\
(-1.68)\end{array}$ & $\begin{array}{l}-0.034 \\
(-0.97)\end{array}$ \\
\hline $\mathrm{I}\left(-50 \%>\mathrm{R}_{\mathrm{t}-11, \mathrm{t}} \geq-100 \%\right)$ & $\begin{array}{l}0.140 * * \\
(2.10)\end{array}$ & $\begin{array}{l}0.014 \\
(0.37)\end{array}$ & $\begin{array}{l}-0.039 * \\
(-1.67)\end{array}$ & $\begin{array}{l}-0.040 \\
(-0.91)\end{array}$ & $\begin{array}{c}-0.122^{* *} \\
(-2.43)\end{array}$ \\
\hline Control Variables & YES & YES & YES & YES & YES \\
\hline Country and Date FEs & YES & YES & YES & YES & YES \\
\hline $\begin{array}{l}\mathrm{N} \\
\text { Adjusted } \mathrm{R}^{2}\end{array}$ & $\begin{array}{c}58442 \\
18.01 \%\end{array}$ & $\begin{array}{c}58442 \\
19.85 \%\end{array}$ & $\begin{array}{c}58442 \\
18.27 \%\end{array}$ & $\begin{array}{c}56962 \\
17.91 \%\end{array}$ & $\begin{array}{c}55545 \\
18.03 \%\end{array}$ \\
\hline
\end{tabular}




\section{Table 5: Global Market Conditions}

This table presents estimates of Equation (2) on subsamples based upon global market conditions. The dependent variables are cumulative return over the interval indicated in the first row. The tests are performed over the subsamples where the average returns from month $\mathrm{t}-11$ to $t$ across all countries is either below (Low) or above (High) the sample median. $I\left(t 1>R_{t-11, t} \geq t 2\right)$ is a dummy variable based upon whether the cumulative return from month $t-11$ to $t$ is below $t 1$ but at least $t 2$. Panel A (Panel B) reports the results without (with) the control variables and fixed effects terms. Control variables from Table 3 are included where indicated, but not reported. Country and date fixed effects are included where indicated, but not reported. Robust standard errors based upon Driscoll and Kraay (1998) estimators are used to calculate $t$-statistics (in parentheses). Statistical significance at the $10 \%, 5 \%$ and $1 \%$ levels are denoted by $*, * *$, and ${ }^{* * *}$, respectively.

\begin{tabular}{|c|c|c|c|c|c|c|}
\hline $\begin{array}{l}\text { Model: } \\
\text { Global Returns Subsample: } \\
\text { Returns Specification: }\end{array}$ & $\begin{array}{c}(1) \\
\text { Low } \\
{[\mathrm{t}+1, \mathrm{t}+12]}\end{array}$ & $\begin{array}{c}(2) \\
\text { Low } \\
{[\mathrm{t}+1, \mathrm{t}+24]}\end{array}$ & $\begin{array}{c}(3) \\
\text { Low } \\
{[\mathrm{t}+1, \mathrm{t}+36]}\end{array}$ & $\begin{array}{c}(4) \\
\text { High } \\
{[t+1, t+12]}\end{array}$ & $\begin{array}{c}(5) \\
\text { High } \\
{[\mathrm{t}+1, \mathrm{t}+24]}\end{array}$ & $\begin{array}{c}(6) \\
\text { High } \\
{[\mathrm{t}+1, \mathrm{t}+36]} \\
\end{array}$ \\
\hline $\mathrm{I}\left(0 \%>\mathrm{R}_{\mathrm{t}-11, \mathrm{t}} \geq-10 \%\right)$ & $\begin{array}{c}-0.043 * * * \\
(-3.79)\end{array}$ & $\begin{array}{c}-0.028 * * * \\
(-3.97)\end{array}$ & $\begin{array}{c}-0.016^{* *} \\
(-2.51)\end{array}$ & $\begin{array}{c}-0.074 * * * \\
(-5.51)\end{array}$ & $\begin{array}{c}-0.025 * * \\
(-2.40)\end{array}$ & $\begin{array}{l}-0.010 \\
(-1.37)\end{array}$ \\
\hline $\mathrm{I}\left(-10 \%>\mathrm{R}_{\mathrm{t}-11, \mathrm{t}} \geq-20 \%\right)$ & $\begin{array}{c}-0.055 * * * \\
(-2.99)\end{array}$ & $\begin{array}{c}-0.030 * * * \\
(-2.68)\end{array}$ & $\begin{array}{l}-0.012 \\
(-1.16)\end{array}$ & $\begin{array}{c}-0.114 * * * \\
(-6.76)\end{array}$ & $\begin{array}{c}-0.058 * * * \\
(-4.18)\end{array}$ & $\begin{array}{c}-0.028 * * * \\
(-2.90)\end{array}$ \\
\hline $\mathrm{I}\left(-20 \%>\mathrm{R}_{\mathrm{t}-11, \mathrm{t}} \geq-30 \%\right)$ & $\begin{array}{c}-0.069 * * * \\
(-2.75)\end{array}$ & $\begin{array}{c}-0.042 * * * \\
(-2.91)\end{array}$ & $\begin{array}{c}-0.022 * \\
(-1.68)\end{array}$ & $\begin{array}{c}-0.123 * * * \\
(-6.57)\end{array}$ & $\begin{array}{c}-0.072 * * * \\
(-4.13)\end{array}$ & $\begin{array}{c}-0.035 * * * \\
(-2.72)\end{array}$ \\
\hline $\mathrm{I}\left(-30 \%>\mathrm{R}_{\mathrm{t}-11, \mathrm{t}} \geq-40 \%\right)$ & $\begin{array}{c}-0.062^{*} \\
(-1.76)\end{array}$ & $\begin{array}{c}-0.058 * * * \\
(-2.64)\end{array}$ & $\begin{array}{c}-0.044 * * \\
(-2.29)\end{array}$ & $\begin{array}{c}-0.126^{* * * *} \\
(-3.66)\end{array}$ & $\begin{array}{c}-0.074 * * * \\
(-3.19)\end{array}$ & $\begin{array}{c}-0.045 * * * \\
(-2.70)\end{array}$ \\
\hline $\mathrm{I}\left(-40 \%>\mathrm{R}_{\mathrm{t}-11, \mathrm{t}} \geq-50 \%\right)$ & $\begin{array}{l}-0.001 \\
(-0.02)\end{array}$ & $\begin{array}{l}-0.036 \\
(-1.11)\end{array}$ & $\begin{array}{c}-0.043^{*} \\
(-1.79)\end{array}$ & $\begin{array}{c}-0.123 * * * \\
(-2.75)\end{array}$ & $\begin{array}{c}-0.101 * * * \\
(-3.40)\end{array}$ & $\begin{array}{c}-0.042 * \\
(-1.83)\end{array}$ \\
\hline $\mathrm{I}\left(-50 \%>\mathrm{R}_{\mathrm{t}-11, \mathrm{t}} \geq-100 \%\right)$ & $\begin{array}{l}0.136^{*} \\
(1.71)\end{array}$ & $\begin{array}{l}0.009 \\
(0.23)\end{array}$ & $\begin{array}{l}-0.047 \\
(-1.63)\end{array}$ & $\begin{array}{c}0.258^{*} \\
(1.80)\end{array}$ & $\begin{array}{l}0.011 \\
(0.15)\end{array}$ & $\begin{array}{l}-0.039 \\
(-0.86)\end{array}$ \\
\hline Control Variables & YES & YES & YES & YES & YES & YES \\
\hline Country and Date FEs & YES & YES & YES & YES & YES & YES \\
\hline $\mathrm{N}$ & 29472 & 29472 & 29472 & 28970 & 28970 & 28970 \\
\hline Adjusted $\mathrm{R}^{2}$ & $19.38 \%$ & $24.96 \%$ & $25.15 \%$ & $20.42 \%$ & $26.56 \%$ & $28.45 \%$ \\
\hline
\end{tabular}




\section{Table 6: Macroeconomic Conditions}

This table presents estimates of Equation (2) with the addition of macroeconomic control variables, using a subsample of markets based upon the availability of the macroeconomic data. Macroeconomic control variables include a depression dummy, the one-year change in real GDP, the one-year change in CPI, a financial crisis dummy, the oneyear change in loan-to-GDP ratio, and the dividend-to-price ratio. Control variables from Table 3 are included where indicated, but not reported. Country and date fixed effects are included where indicated, but not reported. Robust standard errors based upon Driscoll and Kraay (1998) estimators are used to calculate $t$-statistics (in parentheses). Statistical significance at the $10 \%, 5 \%$ and $1 \%$ levels are denoted by $* * *$, and $* * *$, respectively.

\begin{tabular}{|c|c|c|c|c|c|c|}
\hline $\begin{array}{l}\text { Model: } \\
\text { Returns Specification: }\end{array}$ & $\begin{array}{c}(1) \\
{[\mathrm{t}+1, \mathrm{t}+12]}\end{array}$ & $\begin{array}{c}(2) \\
{[t+1, t+24]}\end{array}$ & $\begin{array}{c}(3) \\
{[\mathrm{t}+1, \mathrm{t}+36]} \\
\end{array}$ & $\begin{array}{c}(4) \\
{[t+1, t+12]}\end{array}$ & $\begin{array}{c}(5) \\
{[\mathrm{t}+1, \mathrm{t}+24]} \\
\end{array}$ & $\begin{array}{c}(6) \\
{[t+1, t+36]} \\
\end{array}$ \\
\hline $\mathrm{I}\left(0 \%>\mathrm{R}_{\mathrm{t}-11, \mathrm{t}} \geq-10 \%\right)$ & $\begin{array}{c}-0.032 * * \\
(-2.15)\end{array}$ & $\begin{array}{l}-0.011 \\
(-0.90)\end{array}$ & $\begin{array}{l}0.002 \\
(0.19)\end{array}$ & $\begin{array}{c}-0.026^{*} \\
(-1.88)\end{array}$ & $\begin{array}{l}-0.008 \\
(-0.77)\end{array}$ & $\begin{array}{l}0.001 \\
(0.19)\end{array}$ \\
\hline $\mathrm{I}\left(-10 \%>\mathrm{R}_{\mathrm{t}-11, \mathrm{t}} \geq-20 \%\right)$ & $\begin{array}{c}-0.069 * * * \\
(-2.98)\end{array}$ & $\begin{array}{l}-0.019 \\
(-1.23)\end{array}$ & $\begin{array}{l}-0.001 \\
(-0.11)\end{array}$ & $\begin{array}{c}-0.060 * * * \\
(-2.68)\end{array}$ & $\begin{array}{l}-0.016 \\
(-1.07)\end{array}$ & $\begin{array}{l}-0.002 \\
(-0.19)\end{array}$ \\
\hline $\mathrm{I}\left(-20 \%>\mathrm{R}_{\mathrm{t}-11, \mathrm{t}} \geq-30 \%\right)$ & $\begin{array}{c}-0.077 * * * \\
(-2.63)\end{array}$ & $\begin{array}{c}-0.037^{*} \\
(-1.80)\end{array}$ & $\begin{array}{c}-0.029 * \\
(-1.82)\end{array}$ & $\begin{array}{c}-0.054^{*} \\
(-1.90)\end{array}$ & $\begin{array}{l}-0.024 \\
(-1.25)\end{array}$ & $\begin{array}{l}-0.024 \\
(-1.52)\end{array}$ \\
\hline $\mathrm{I}\left(-30 \%>\mathrm{R}_{\mathrm{t}-11, \mathrm{t}} \geq-40 \%\right)$ & $\begin{array}{l}-0.047 \\
(-1.10)\end{array}$ & $\begin{array}{l}-0.031 \\
(-1.09)\end{array}$ & $\begin{array}{c}-0.041^{*} \\
(-1.82)\end{array}$ & $\begin{array}{l}-0.021 \\
(-0.50)\end{array}$ & $\begin{array}{l}-0.016 \\
(-0.61)\end{array}$ & $\begin{array}{l}-0.035 \\
(-1.57)\end{array}$ \\
\hline $\mathrm{I}\left(-40 \%>\mathrm{R}_{\mathrm{t}-11, \mathrm{t}} \geq-50 \%\right)$ & $\begin{array}{l}-0.060 \\
(-0.98)\end{array}$ & $\begin{array}{c}-0.080^{*} \\
(-1.90)\end{array}$ & $\begin{array}{c}-0.091^{* * *} \\
(-2.65)\end{array}$ & $\begin{array}{l}-0.022 \\
(-0.39)\end{array}$ & $\begin{array}{l}-0.059 \\
(-1.56)\end{array}$ & $\begin{array}{c}-0.079^{* *} \\
(-2.44)\end{array}$ \\
\hline $\mathrm{I}\left(-50 \%>\mathrm{R}_{\mathrm{t}-11, \mathrm{t}} \geq-100 \%\right)$ & $\begin{array}{c}0.259 * * * \\
(2.64)\end{array}$ & $\begin{array}{l}0.042 \\
(0.66)\end{array}$ & $\begin{array}{l}0.012 \\
(0.27)\end{array}$ & $\begin{array}{c}0.253 * * * \\
(2.73)\end{array}$ & $\begin{array}{l}0.019 \\
(0.36)\end{array}$ & $\begin{array}{l}-0.015 \\
(-0.36)\end{array}$ \\
\hline Depressiont $_{t}$ & & & & $\begin{array}{c}-0.137 * * * \\
(-5.03)\end{array}$ & $\begin{array}{c}-0.118 * * * \\
(-5.43)\end{array}$ & $\begin{array}{c}-0.097 * * * \\
(-5.59)\end{array}$ \\
\hline Change in Real GDP $\mathrm{t}_{\mathrm{t}-11, \mathrm{t}}$ & & & & $\begin{array}{l}-0.247 \\
(-0.94)\end{array}$ & $\begin{array}{c}-0.383 * * \\
(-2.12)\end{array}$ & $\begin{array}{c}-0.435 * * * \\
(-3.33)\end{array}$ \\
\hline Change in $\mathrm{CPI}_{\mathrm{t}-11, \mathrm{t}}$ & & & & $\begin{array}{c}-0.683 * * * \\
(-4.46)\end{array}$ & $\begin{array}{c}-0.573 * * * \\
(-5.55)\end{array}$ & $\begin{array}{c}-0.413 * * * \\
(-4.58)\end{array}$ \\
\hline Financial Crisist & & & & $\begin{array}{c}-0.101 * * * \\
(-2.58)\end{array}$ & $\begin{array}{c}-0.053 * * \\
(-2.24)\end{array}$ & $\begin{array}{c}-0.038^{* *} \\
(-2.31)\end{array}$ \\
\hline Change in $(\text { Loan/GDP })_{\mathrm{t}-11, \mathrm{t}}$ & & & & $\begin{array}{c}0.395 * * * \\
(2.70)\end{array}$ & $\begin{array}{l}0.105 \\
(0.76)\end{array}$ & $\begin{array}{l}-0.123 \\
(-1.30)\end{array}$ \\
\hline$(\mathrm{D} / \mathrm{P})_{\mathrm{t}}$ & & & & $\begin{array}{c}0.078^{* * *} \\
(3.23)\end{array}$ & $\begin{array}{c}0.076^{* * *} \\
(3.96)\end{array}$ & $\begin{array}{c}0.066^{* * * *} \\
(4.19)\end{array}$ \\
\hline Control Variables & YES & YES & YES & YES & YES & YES \\
\hline Country and Date FEs & YES & YES & YES & YES & YES & YES \\
\hline $\begin{array}{l}\mathrm{N} \\
\text { Adjusted } \mathrm{R}^{2}\end{array}$ & $\begin{array}{c}10765 \\
47.86 \%\end{array}$ & $\begin{array}{c}10765 \\
54.69 \%\end{array}$ & $\begin{array}{c}10765 \\
58.72 \%\end{array}$ & $\begin{array}{c}10765 \\
48.92 \%\end{array}$ & $\begin{array}{c}10765 \\
56.35 \%\end{array}$ & $\begin{array}{c}10765 \\
60.53 \%\end{array}$ \\
\hline
\end{tabular}




\section{Table 7: Political Conflicts}

This table presents estimates of Equation (2) with the addition of political conflict indicators from the International Crisis Behavior (ICB) Project, using a subsample of markets based upon the availability of the ICB data. Start of Conflict, Middle of Conflict, and End of Conflict are dummies based upon whether month $t$ is at the start, in the middle, or at the end of the conflict, respectively. Macroeconomic control variables include a depression dummy, the one-year change in real GDP, the one-year change in CPI, a financial crisis dummy, the one-year change in loan-toGDP ratio, and the dividend-to-price ratio. Control variables from Table 3 are included where indicated, but not reported. Country and date fixed effects are included where indicated, but not reported. Robust standard errors based upon Driscoll and Kraay (1998) estimators are used to calculate $t$-statistics (in parentheses). Statistical significance at the $10 \%, 5 \%$ and $1 \%$ levels are denoted by $*, * *$, and $* * *$, respectively.

\begin{tabular}{|c|c|c|c|c|c|c|}
\hline$\frac{\text { Model: }}{\text { Returns Specification: }}$ & $\begin{array}{c}(1) \\
{[\mathrm{t}+1, \mathrm{t}+12]}\end{array}$ & $\begin{array}{c}(2) \\
{[\mathrm{t}+1, \mathrm{t}+24]}\end{array}$ & $\begin{array}{c}(3) \\
{[\mathrm{t}+1, \mathrm{t}+36]}\end{array}$ & $\begin{array}{c}(4) \\
{[t+1, t+12]}\end{array}$ & $\begin{array}{c}(5) \\
{[\mathrm{t}+1, \mathrm{t}+24]} \\
\end{array}$ & $\begin{array}{c}(6) \\
{[\mathrm{t}+1, \mathrm{t}+36]}\end{array}$ \\
\hline $\mathrm{I}\left(0 \%>\mathrm{R}_{\mathrm{t}-11, \mathrm{t}} \geq-10 \%\right)$ & $\begin{array}{c}-0.068 * * * \\
(-6.32)\end{array}$ & $\begin{array}{c}-0.026 * * * \\
(-3.18)\end{array}$ & $\begin{array}{c}-0.010 * \\
(-1.78)\end{array}$ & $\begin{array}{c}-0.028 * \\
(-1.83)\end{array}$ & $\begin{array}{l}-0.011 \\
(-0.89)\end{array}$ & $\begin{array}{l}0.002 \\
(0.29)\end{array}$ \\
\hline $\mathrm{I}\left(-10 \%>\mathrm{R}_{\mathrm{t}-11, \mathrm{t}} \geq-20 \%\right)$ & $\begin{array}{c}-0.094 * * * \\
(-6.83)\end{array}$ & $\begin{array}{c}-0.040 * * * \\
(-3.71)\end{array}$ & $\begin{array}{c}-0.015^{*} \\
(-1.88)\end{array}$ & $\begin{array}{c}-0.066 * * * \\
(-2.85)\end{array}$ & $\begin{array}{l}-0.022 \\
(-1.38)\end{array}$ & $\begin{array}{l}-0.004 \\
(-0.34)\end{array}$ \\
\hline $\mathrm{I}\left(-20 \%>\mathrm{R}_{\mathrm{t}-11, \mathrm{t}} \geq-30 \%\right)$ & $\begin{array}{c}-0.104 * * * \\
(-6.29)\end{array}$ & $\begin{array}{c}-0.051 * * * \\
(-4.11)\end{array}$ & $\begin{array}{c}-0.023 * * \\
(-2.54)\end{array}$ & $\begin{array}{c}-0.062^{* *} \\
(-2.12)\end{array}$ & $\begin{array}{l}-0.027 \\
(-1.38)\end{array}$ & $\begin{array}{l}-0.024 \\
(-1.48)\end{array}$ \\
\hline $\mathrm{I}\left(-30 \%>\mathrm{R}_{\mathrm{t}-11, \mathrm{t}} \geq-40 \%\right)$ & $\begin{array}{c}-0.100 * * * \\
(-3.96)\end{array}$ & $\begin{array}{c}-0.063 * * * \\
(-3.49)\end{array}$ & $\begin{array}{c}-0.041^{* * * *} \\
(-3.34)\end{array}$ & $\begin{array}{l}-0.031 \\
(-0.71)\end{array}$ & $\begin{array}{l}-0.019 \\
(-0.70)\end{array}$ & $\begin{array}{l}-0.037 \\
(-1.55)\end{array}$ \\
\hline $\mathrm{I}\left(-40 \%>\mathrm{R}_{\mathrm{t}-11, \mathrm{t}} \geq-50 \%\right)$ & $\begin{array}{l}-0.038 \\
(-0.89)\end{array}$ & $\begin{array}{l}-0.046 \\
(-1.54)\end{array}$ & $\begin{array}{c}-0.039 * * \\
(-2.50)\end{array}$ & $\begin{array}{l}-0.029 \\
(-0.47)\end{array}$ & $\begin{array}{l}-0.065 \\
(-1.59)\end{array}$ & $\begin{array}{c}-0.084^{* *} \\
(-2.41)\end{array}$ \\
\hline $\mathrm{I}\left(-50 \%>\mathrm{R}_{\mathrm{t}-11, \mathrm{t}} \geq-100 \%\right)$ & $\begin{array}{c}0.152 * * \\
(2.26)\end{array}$ & $\begin{array}{l}0.026 \\
(0.73)\end{array}$ & $\begin{array}{l}-0.025 \\
(-1.17)\end{array}$ & $\begin{array}{c}0.246 * * * \\
(2.66)\end{array}$ & $\begin{array}{l}0.011 \\
(0.21)\end{array}$ & $\begin{array}{l}-0.022 \\
(-0.53)\end{array}$ \\
\hline Start of Conflict $t-11, t$ & $\begin{array}{l}0.030 \\
(1.16)\end{array}$ & $\begin{array}{c}0.043^{* *} \\
(2.20)\end{array}$ & $\begin{array}{c}0.026^{* *} \\
(2.10)\end{array}$ & $\begin{array}{c}0.079 * * * \\
(2.72)\end{array}$ & $\begin{array}{c}0.057 * * * \\
(2.88)\end{array}$ & $\begin{array}{c}0.035^{* * *} \\
(2.63)\end{array}$ \\
\hline Middle of Conflict $\mathrm{t}-11, \mathrm{t}$ & $\begin{array}{l}-0.044 \\
(-1.22)\end{array}$ & $\begin{array}{c}-0.044^{*} \\
(-1.75)\end{array}$ & $\begin{array}{c}-0.042 * * \\
(-2.34)\end{array}$ & $\begin{array}{l}-0.040 \\
(-1.16)\end{array}$ & $\begin{array}{c}-0.045^{*} \\
(-1.76)\end{array}$ & $\begin{array}{c}-0.037^{*} \\
(-1.91)\end{array}$ \\
\hline End of Conflict $t_{\mathrm{t}-11, \mathrm{t}}$ & $\begin{array}{l}0.007 \\
(0.25)\end{array}$ & $\begin{array}{l}0.007 \\
(0.34)\end{array}$ & $\begin{array}{l}0.013 \\
(0.89)\end{array}$ & $\begin{array}{l}0.010 \\
(0.31)\end{array}$ & $\begin{array}{l}0.010 \\
(0.50)\end{array}$ & $\begin{array}{l}0.015 \\
(0.93)\end{array}$ \\
\hline Macro Control Variables & NO & NO & NO & YES & YES & YES \\
\hline Control Variables & YES & YES & YES & YES & YES & YES \\
\hline Country and Date FEs & YES & YES & YES & YES & YES & YES \\
\hline $\begin{array}{l}\mathrm{N} \\
\text { Adjusted } \mathrm{R}^{2}\end{array}$ & $\begin{array}{c}50834 \\
22.07 \%\end{array}$ & $\begin{array}{c}50834 \\
29.92 \%\end{array}$ & $\begin{array}{c}50834 \\
32.64 \%\end{array}$ & $\begin{array}{c}9877 \\
49.20 \%\end{array}$ & $\begin{array}{c}9877 \\
56.22 \%\end{array}$ & $\begin{array}{c}9877 \\
60.15 \%\end{array}$ \\
\hline
\end{tabular}




\section{Table 8: Returns in Years Following Crash Events Using JG and DMS Sample}

This table presents estimates of regression models using the JG and DMS sample. The dependent variables are annual returns over the interval indicated in the first row. $I\left(t 1>R_{t-11, t} \geq t 2\right)$ is a dummy variable based upon whether the cumulative return from month $t-11$ to $t$ is below $t 1$ but at least $t 2$. Panel A (Panel B) reports the results without (with) the control variables and fixed effects terms. Fixed effects on the country and year levels are included where indicated, but are not reported. The control variables include annual returns from year t, $\mathrm{t}-1$ and $\mathrm{t}-2$. Macroeconomic control variables include a depression dummy, the one-year change in real GDP, the one-year change in CPI, a financial crisis dummy, the one-year change in loan-to-GDP ratio, and the dividend-to-price ratio. Robust standard errors based upon Driscoll and Kraay (1998) estimators are used to calculate $t$-statistics (in parentheses). Statistical significance at the $10 \%, 5 \%$ and $1 \%$ levels are denoted by $*, * *$, and $* * *$, respectively.

\begin{tabular}{|c|c|c|c|c|c|c|}
\hline$\frac{\text { Model: }}{\text { Returns Specification: }}$ & $\begin{array}{c}(1) \\
{[\mathrm{t}+1, \mathrm{t}+12]}\end{array}$ & $\begin{array}{c}(2) \\
{[t+1, t+24]}\end{array}$ & $\begin{array}{c}(3) \\
{[t+1, t+36]}\end{array}$ & $\begin{array}{c}(4) \\
{[t+1, t+12]}\end{array}$ & $\begin{array}{c}(5) \\
{[t+1, t+24]}\end{array}$ & $\begin{array}{c}(6) \\
{[t+1, t+36]}\end{array}$ \\
\hline $\mathrm{I}\left(0 \%>\mathrm{R}_{\mathrm{t}-11, \mathrm{t}} \geq-10 \%\right)$ & $\begin{array}{l}-0.041 \\
(-1.66)\end{array}$ & $\begin{array}{l}-0.015 \\
(-0.93)\end{array}$ & $\begin{array}{l}0.002 \\
(0.21)\end{array}$ & $\begin{array}{l}-0.021 \\
(-0.66)\end{array}$ & $\begin{array}{l}-0.028 \\
(-1.31)\end{array}$ & $\begin{array}{l}-0.003 \\
(-0.23)\end{array}$ \\
\hline $\mathrm{I}\left(-10 \%>\mathrm{R}_{\mathrm{t}-11, \mathrm{t}} \geq-20 \%\right)$ & $\begin{array}{c}-0.061 * * * \\
(-2.77)\end{array}$ & $\begin{array}{l}-0.007 \\
(-0.37)\end{array}$ & $\begin{array}{l}0.002 \\
(0.19)\end{array}$ & $\begin{array}{l}-0.007 \\
(-0.15)\end{array}$ & $\begin{array}{l}0.018 \\
(0.53)\end{array}$ & $\begin{array}{l}0.022 \\
(0.85)\end{array}$ \\
\hline $\mathrm{I}\left(-20 \%>\mathrm{R}_{\mathrm{t}-11, \mathrm{t}} \geq-30 \%\right)$ & $\begin{array}{c}-0.070 * * * \\
(-2.69)\end{array}$ & $\begin{array}{l}-0.009 \\
(-0.47)\end{array}$ & $\begin{array}{l}0.005 \\
(0.33)\end{array}$ & $\begin{array}{l}-0.033 \\
(-0.53)\end{array}$ & $\begin{array}{l}0.031 \\
(1.09)\end{array}$ & $\begin{array}{l}0.038 \\
(1.38)\end{array}$ \\
\hline $\mathrm{I}\left(-30 \%>\mathrm{R}_{\mathrm{t}-11, \mathrm{t}} \geq-40 \%\right)$ & $\begin{array}{l}0.022 \\
(0.41)\end{array}$ & $\begin{array}{l}0.042 \\
(1.10)\end{array}$ & $\begin{array}{l}0.033 \\
(1.31)\end{array}$ & $\begin{array}{l}0.106 \\
(1.57)\end{array}$ & $\begin{array}{l}0.070 \\
(1.60)\end{array}$ & $\begin{array}{l}0.039 \\
(1.10)\end{array}$ \\
\hline $\mathrm{I}\left(-40 \%>\mathrm{R}_{\mathrm{t}-11, \mathrm{t}} \geq-50 \%\right)$ & $\begin{array}{l}-0.011 \\
(-0.12)\end{array}$ & $\begin{array}{l}0.024 \\
(0.41)\end{array}$ & $\begin{array}{l}0.013 \\
(0.38)\end{array}$ & $\begin{array}{l}0.104 \\
(0.78)\end{array}$ & $\begin{array}{l}0.048 \\
(0.62)\end{array}$ & $\begin{array}{l}-0.016 \\
(-0.28)\end{array}$ \\
\hline $\mathrm{I}\left(-50 \%>\mathrm{R}_{\mathrm{t}-11, \mathrm{t}} \geq-100 \%\right)$ & $\begin{array}{c}0.343 * * \\
(2.10)\end{array}$ & $\begin{array}{l}0.128^{*} \\
(1.67)\end{array}$ & $\begin{array}{l}0.043 \\
(1.10)\end{array}$ & $\begin{array}{l}0.542 * * * \\
(3.49)\end{array}$ & $\begin{array}{l}0.193^{* * *} \\
(3.00)\end{array}$ & $\begin{array}{c}0.115^{* *} \\
(2.52)\end{array}$ \\
\hline Macro Control Variables & NO & NO & NO & YES & YES & YES \\
\hline Control Variables & NO & NO & NO & YES & YES & YES \\
\hline Country and Date FEs & NO & $\mathrm{NO}$ & $\mathrm{NO}$ & YES & YES & YES \\
\hline $\mathrm{N}$ & 3533 & 3482 & 3431 & 918 & 918 & 918 \\
\hline Adjusted $\mathrm{R}^{2}$ & $2.04 \%$ & $0.55 \%$ & $0.14 \%$ & $48.88 \%$ & $53.90 \%$ & $55.24 \%$ \\
\hline
\end{tabular}

